MIPLC Studies

Esther Seitz

Fact-Gathering in Patent Infringement Cases: Rule 34 Discovery and the Saisie-Contrefaçon

\title{
Nomos MIPLC
}







Esther Seitz

Fact-Gathering in Patent Infringement

Cases: Rule 34 Discovery and the

Saisie-Contrefaçon 
Die Deutsche Nationalbibliothek verzeichnet diese Publikation in der Deutschen Nationalbibliografie; detaillierte bibliografische Daten sind im Internet über http://dnb.d-nb.de abrufbar.

The Deutsche Nationalbibliothek lists this publication in the Deutsche Nationalbibliografie; detailed bibliographic data is available in the Internet at http://dnb.d-nb.de .

a.t.: Munich, Munich Intellectual Property Law Center, LL.M., Thesis, 2008

ISBN 978-3-8329-4855-9

\section{Auflage 2009}

(c) Nomos Verlagsgesellschaft, Baden-Baden 2009. Printed in Germany. Alle Rechte, auch die des Nachdrucks von Auszügen, der fotomechanischen Wiedergabe und der Übersetzung, vorbehalten. Gedruckt auf alterungsbeständigem Papier.

This work is subject to copyright. All rights are reserved, whether the whole or part of the material is concerned, specifically those of translation, reprinting, re-use of illustrations, broadcasting, reproduction by photocopying machine or similar means, and storage in data banks. Under $§ 54$ of the German Copyright Law where copies are made for other than private use a fee is payable to "Verwertungsgesellschaft Wort", Munich. 
The author would like to thank her parents,

Iris and Günter Seitz,

for making all of her academic endeavors a possibility. Further, the author thanks Professor Paul Goldstein for his guidance with this project. 


\section{Table of Contents}

I. Introduction 9

II. Federal Rules Discovery 11

A. Rule $34 \quad 15$

1. Inspection of Things - Types of Items Covered 16

2. Premise Inspections 17

3. Custody, Possession, Control 18

4. Obligaton to Preserve and Spoliations 19

B. Context of Rule 34 amid Other Discovery Rules 19

1. Privileges 20

2. Protective Orders 21

3. Motions to Compel and Sanctions 22

III. Saisie-Contrefacon 23

A. Before the Saisie: Ex Parte Application for Inspection 24

B. During the Saisie: Carrying out the Order 26

C. After the Saisie: Suit and Possibility for Appeal 29

IV. Comparing and Contrasting Basic Aspects of the Saisie and Rule 34

V. Specific Patent-Related Aspects of Evidence Gathering 35
A. Third Party Production 35

B. Trade Secrets and Secret Commercial Information 36

C. Costs 38

D. Duration 39

E. Extraterritorial Application 40

VI. Evaluative Comparison of the Procedures' Strengths 45

VII. Conclusion 49

List of Works Cited $\quad 51$ 


\section{Introduction}

"Inventions, their exploitation, and the related prior art being inherently scientific and technical in nature, have a proclivity for recordation of information directed to their development, particulars of construction, modification, and application in documents." ${ }^{11}$ In fact, documents, tangible items and processes embody the most vital evidence available for proving patent validity and infringement. ${ }^{2}$ As such, document discovery constitutes the evidentiary foundation of most patent infringement actions. $^{3}$

In United States law, Rule 34 of the Federal Rules of Civil Procedure (Federal Rules or Rules) addresses production of documents, tangible things and inspection of premises. ${ }^{4}$ In French law, the Saisie-Contrefaçon (Saisie) secures production of documents, tangible things and inspection of premises, although its procedural approach differs considerably. ${ }^{5}$ This thesis compares and contrasts the objectives, practices, policies and implications of discovery under Federal Rule 34 and the Saisie in the context of patent infringement cases.

First, this thesis explains how litigants in patent infringement actions conduct discovery under the Federal Rules and, specifically, Rule $34 .{ }^{6}$ Second, it outlines the Saisie in the patent infringement context. ${ }^{7}$ Third, it compares and contrasts some basic features of the two procedures. ${ }^{8}$ Fourth, it turns to some more specific aspects of evidence-gathering that tend to assume significance in patent suits by further juxtaposing Rule 34 and the Saisie. ${ }^{9}$ Fifth, this thesis evaluates the two procedures in comparison and judges which aspects of each better support patent policy. ${ }^{10}$ Finally, this thesis concludes by opining which features of Rule 34 discovery and the Saisie will best serve patent policy in the future. ${ }^{11}$

1 Kenneth R. Adamo et al., Document Discovery in Patent Litigation, in Patent LitigAtion STRATEGies HandBook 2004 Cumulative Supplement 79, 79 (Barry L. Grossman \& Gary M. Hoffman eds., BNA Books 2004).

2 See id.

$3 \quad$ Id.

4 See FED. R. CIV. P. 34.

5 See e.g. Art. L 615-5 Code de la propriété intellectuelle (CPI); Art. L 615-5-1 CPI; Art. R 615-1 CPI; Art. R 615-2 CPI; Art. R 615-4 CPI.

See infra Part II.

See infra Part III.

See infra Part IV.

See infra Part V.

10 See infra Part VI.

11 See infra Part VII. 


\section{Federal Rules Discovery}

In contrast to civil law systems, where litigation proceeds along a continuum with frequent hearings and constant involvement by the judge, litigation in the United States consists of two distinct phases: the pre-trial and trial phases. ${ }^{12}$ The former, including service of process, pleading, evidence-gathering, and summary judgment involves relatively slight judicial supervision. ${ }^{13}$ Discovery ${ }^{14}$ in the United States relies on the adversaries to gather and develop the facts underlying a lawsuit. ${ }^{15}$ Accordingly, the judge ${ }^{16}$ only narrowly supervises the discovery process. ${ }^{17}$ The Federal Rules direct the parties to learn as much relevant and nonprivileged information as possible about the case and resort to the courts only in case of irreconcilable conflicts. ${ }^{18}$

Discovery is rightfully deemed "broad." 19 This broadness appears in three different ways. First, discovery applies to all types of civil litigation, irrespective of the legal field and relief sought. ${ }^{20}$ Accordingly, evidence procurement in products liability, divorce or patent infringement cases all follow the Federal Rules' discovery procedures, whether they request injunctions, monetary damages, or other relief. Second, all civil litigants procure potential evidence by means of discovery, regardless of their

12 Oscar G. Chase et al., Civil Litigation in Comparative Context, 28 (Oscar G. Chase and Helen Hershkoff eds., Thomson/West 2007); see also ABBo JUNKER, DisCOVERY IM DEUTSCHAMERIKANISCHEN RECHTSVERKEHR 97 (Otto Sandrock ed., Verlag Recht und Wirtschaft GmbH 1987).

13 Valerie Davies \& Thomas N. Pieper, English Disclosure and U.S. Discovery, in TransatLANTIC COMmercial Litigation AND ARbitration, 233, 233 - 235 (John Fellas ed., Oceana Publications 2004) (stating that the parties' attorneys drive U.S. discovery while courts take rather passive roles). However, the pretrial phase has received increasing attention by the courts as procedural reforms encourage judges' proactivness regarding case management. Stephen B. Burbank \& Linda J. Silberman, Civil Procedure Reform in Comparative Context: The United States of America, 45 AM. J. CoM. L. 675, 678 - 683 (1997); see also FED. R. CIV. P. 16 (instructing trial judges to use pretrial conferences to speed up the pretrial process and encourage settlement); see also 6 JAMES WM. MOORE ET AL., MoORE’s FederAL PRACTICE $\$ 26.05$ (Matthew Bender 3d ed. 2008) (suggesting that "direct judicial involvement, particularly access by the parties to the judge and judicial activity, are ... important elements of any soundly managed program of discovery" which can help alleviate difficulties in conducting discovery especially in large and complex lawsuits).

14 Unless otherwise indicated, "discovery" as used herein refers to discovery under the Federal Rules of Civil Procedure.

15 Davies \& Pieper, English Disclosure and U.S. Discovery, in TransatlantiC CommERCIAL LiTIGATION AND ARBITRATION, supra note 13, at $233-235$.

16 Discovery matters are more and more handled by federal magistrate judges in the first instance.

17 See e.g. CHASE ET AL., supra note 12, at $14-15$ (discussing the relative passivity of U.S. judges visà-vis their civil law counterparts).

18 CHASE ET AL., supra note 12, at 29. The extent and manner in which these devices are employed by the parties remain subject to judicial control. Id.

19 JUNKER, supra note 12, at 117 (explaining that discoverability is best understood as including anything which is not expressly excluded); GARY B. BORN \& DAVID WESTIN, INTERNATIONAL CIVIL LITIGATION IN UNITED STATES COURTS: COMMENTARY AND MATERIALS 262 (Kluwer 1989); see e.g. CHASE ET AL., supra note 12, at 30 (stating that the recent trend has favored a more restrictive interpretation of discovery.)

20 Hickman v. Taylor, 329 U.S. 495, 507 (1947) stating that discovery is not a "one-way proposition." Instead, "[i]t is available in all types of cases at the behest of any party, individual or corporate, plaintiff or defendant." Id. (emphasis added). 
legal entity status or whether they are plaintiffs or defendants. ${ }^{21}$ Third, discovery liberally authorizes parties to seek wide-ranging types of information from each other, regardless of their written, oral or digital form or confidential status. ${ }^{22}$

Courts in patent infringement suits have traditionally exercised relatively tight control over discovery and effectively limited it to the precise issues raised in the pleadings. ${ }^{23}$ As a result, information regarding patent validity is deemed non-discoverable without an invalidity defense. ${ }^{24}$ Further, courts have required precision of and imposed reasonable limitations on discovery requests concerning production deadlines and subject matter. ${ }^{25}$

Federal Rules of Civil Procedure 26 through 37 govern evidence-gathering in patent infringement lawsuits in United States federal courts. ${ }^{26}$ Rule 26 constitutes an umbrella rule, which, generally, outlines discoverability and to which the following discovery rules are subject. ${ }^{27}$

First, Rule 30 depositions represent the most widely employed and internationally criticized $^{28}$ discovery device. ${ }^{29}$ Any party or non-party with information relevant to the actions may be deposed. ${ }^{30}$ Depositions usually take place in the law offices of the attorneys. ${ }^{31}$ The deponent must give an oath of truthfulness in front of a notary and a court reporter takes a verbatim record of the questioning. ${ }^{32}$ The deponents then undergo interrogation by both parties ${ }^{33}$ as they would at trial. ${ }^{34}$ The relative inefficiency of oral questioning and the mandated presence of counsel make depositions relatively time-consuming and expensive. ${ }^{35}$ The availability of oral depositions in the United States contrasts starkly with procedural tools available elsewhere; even in

21 See 6 MOORE ET AL., supra note 13, at $\S \S 26.03$. However, Federal Rule 81 curbs discovery's breadth by limiting its application and rendering it entirely inapplicable in special cases such as prize proceedings in admiralty, habeas corpus, bankruptcy, administrative actions. FED. R. CIV. P. 81.

22 Fed. R. Civ. P. 26(b)(1); JACK H. Frickenthal, ARTHUR R. Miller, JoHn E. SEXTON, AND Helen Hershkoff, Civil Procedure: CASES AND MATERials, 735 - 736 (9th ed. 2005).

236 MOORE ET AL., supra note 13, at \$26.46[12][a].

24 See e.g., Meese v. Eaton Mfg Co., 35 F.R.D. 162, 165 (N.D. Ohio 1964) (information relating to how the patented invention was conceived, its subsequent trials and disclosures deemed irrelevant and nondiscoverable absent a claim of invalidity).

256 MoORE ET AL., supra note 13, at \$26.46[12][a]; V. D. Anderson Co. v. Helena Cotton Oil Co., 117 F.Supp. 932, 950 (E.D. Ark. 1953) (mandating reformulation of "useful" subject matter and requests for data implicating a 20 -year time span).

26 Fed. R. CiV. P. 26 - 37; 8 Charles Alan Wright \& Arthur R. Miller, Federal Practice and PROCEDURE $§ 2003$ (2d ed. 1987). For a comprehensive background discussion on the development of discovery procedure in the federal courts see Note, Developments in the Law - Discovery, 74 HARV. L. REV. 940, 949 (1961).

27 See FED. R. CiV. P. 26.

28 BORN \& WESTIN, supra note 19, at 262.

29 FED. R. CIV. P. 30. Depositions are usually oral but may be written as well. Rule 31 addresses written depositions.

30 Parties need only be given "reasonable notice" of the deposition, while non-parties must be subpoenaed by the court or an attorney. See FED. R. CIV. P. 45(a)(3).

314 AM. JUR. Trials $\S 30$ (2008).

32 Id. at $\S 27$.

33 However, the right of cross-examination is not uniformly accepted. Id. at $\S 36$. ("It is a matter of conflicting opinion whether or not a right to cross-examine exists in favor of a party whose deposition has been taken, when the deposition is strictly a discovery proceeding under the modern rules.")

34 Id

$35 I d$. at $\S 2$. 
other common law countries that permit them, their availability is restricted to parties and extends to non-parties only in extraordinary cases. ${ }^{36}$

Second, interrogatories under Rule 33 follow depositions in popularity. ${ }^{37}$ They, however, may only be addressed to parties and seek written responses under oath. ${ }^{38}$ Parties usually consult their attorneys in answering the questions. ${ }^{39}$ Thus, while interrogatories, at first glance, present a relatively cheap and simple discovery device, the potential need to follow up on questions and the responding parties' ability to dodge potentially risky issues can make their use rather cumbersome. ${ }^{40}$

Third, Rule 35 physical and mental examinations constitute a more sensitive and intrusive discovery device. ${ }^{41}$ As a result, they remain subject to strict control of the courts that honor requests for such examination only upon a showing of "good cause." 42 They are, generally, limited to parties and persons under their legal control. $^{43}$

Fourth, Rule 36 admissions help in framing the issues and facts in controversy. An admission made during discovery generally determines an issue with regard to that action. ${ }^{44}$ Admissions are limited to the adversaries and involve the exchange of questions among them. ${ }^{45}$ The receiving party may respond affirmatively or negatively, refuse to answer or object based on irrelevance or privilege. ${ }^{46}$ However, under Rule 36(a) an objection is not warranted on the sole basis that it involves a core issue in the litigation. $^{47}$

Supporters ${ }^{48}$ of discovery's broadness point to the elimination of surprise, the open, well-informed and fair progress of litigation and efficiency as policy goals. ${ }^{49}$ Additionally, the "powerful federal engine of discovery" promotes the public interest and good social policy via private actions initiated by private attorneys generals. ${ }^{50}$ In such suits, social policy favors that plaintiffs discover as much pertinent evidence as possible from defendants. ${ }^{51}$ Thus, "[c]alibration of discovery is calibration of the level or

36 CHASE ET AL., supra note 12, at 29 - 30 (explaining their more limited applicability in Canada) (2007); see also, in the United Kingdom, Civil Procedure Rules (CPR) 34.8 .

37 FED. R. CIV. P. 33. Interrogatories and exchange of documents also exist in most other common law systems. CHASE ET AL., supra note 12, at 29.

38 FED. R. CIV. P. 33(a)-(b).

39 See 23 AM. JUR. 2D Depositions and Discovery $\S 125$ (2008).

40 See Edwin W. Green \& Douglas S. Brown, Back to the Future: Proposals for Restructuring Civil Discovery, 26 U.S.F. L. REV. 225, 233 (1992).

41 Despite its inherent intrusiveness into a person's physical and emotional privacy, this discovery device has withstood attacks based on the Constitution and the doctor-patient privilege. Sibbach v. Wilson, 312 U.S. 1 (1941).

42 FED. R. CIV. P. 35. A showing of "good cause" requires more than "relevance;" the requesting party must demonstrate why and that the evidence is necessary and can not be attained otherwise.

43 Id. at $35(\mathrm{a})$.

44 Id. at 36(b).

45 Id. at 36(a).

46 See id.

$47 \quad I d$.

48 See e.g. Miner v. Atlass, 363 U.S. 641, 649 (1960) (referring to the discovery rules as "one of the major achievements of the Civil Rules.")

49 Federal Deposit Ins. Corp. v. Cherry, Bekaert \& Holland, 131 F.R.D. 202, 204 (M.D. Fla. 1990) (aim of liberal discovery rules is to make trials less of a game of "blindman's bluff" and more of a fair contest); 6 MOORE ET AL., supra note 13, at $\$ 26.02$ ("Liberal pretrial discovery tends to foster simplicity in pleading by permitting the pleadings to assume the form of generalized statements.")

50 Patrick E. Higginbotham, Foreword, 49 ALA. L. REV. 1, 4 - 5 (1997).

$51 \quad I d$. 
enforcement of the social policy set by Congress.. ${ }^{, 52}$ The United States legal system heavily relies on suits brought by private litigants due to the system's relative freedom from regulation and bureaucratization. ${ }^{53}$ Therefore, Professor Carrington reasons, U.S. plaintiffs require adequate - and possibly superior - discovery tools:

Private litigants do in America much of what is done in other industrial states by public officers working within an administrative bureaucracy. Every day, hundreds of American lawyers caution their clients that an unlawful course of conduct will be accompanied by serious risk of exposure at the hands of some hundreds or thousands of lawyers, each armed with a subpoena power by which misdeeds can be uncovered. Unless corresponding new powers are conferred on public officers, constricting discovery would diminish the disincentives for lawless behavior across a wide spectrum of forbidden conduct. ${ }^{54}$

In patent infringement cases, Rule 34 represents the key discovery device. ${ }^{55}$ It covers the production of documents, tangible things and the inspection of premises. Inventors' increasing reliance on the internet and computer technologies for conducting and documenting research and development amplifies Rule 34's significance as a discovery device ${ }^{56}$ Rule 34, titled "Producing Documents, Electronically Stored Information, and Tangible Things, or Entering onto Land, for Inspection and Other Purposes," subdivides into three subsections outlining the scope of the inspection, its procedures and deadlines, and third party production. ${ }^{57}$

52 Id.

53 See Paul D. Carrington, Renovating Discovery, 49 ALA. L. REV. 51, 54 (1997).

54 Id.; see also JUNKER, supra note 12, at 96 (explaining that in contrast to German law, private plaintiffs in the United States, motivated by treble damages, sue and thereby perform a "Gewerbeaufsichtsfunktion" or business monitoring function which in Germany constitutes the task of federal agencies).

55 E.g. Kenneth R. Adamo et al., Document Discovery in Patent Litigation, in PATENT LITIGATION STRATEGIES HANDBOOK 2004 CUMULATIVE SuPPlEMENT supra note 1, at 79.

56 Id.

57 (a) In General. A party may serve on any other party a request within the scope of Rule 26(b):

(1) to produce and permit the requesting party or its representative to inspect, copy, test, or sample the following items in the responding party's possession, custody, or control:

(A) any designated documents or electronically stored information--including writings, drawings, graphs, charts, photographs, sound recordings, images, and other data or data compilations--stored in any medium from which information can be obtained either directly or, if necessary, after translation by the responding party into a reasonably usable form; or

(B) any designated tangible things; or

(2) to permit entry onto designated land or other property possessed or controlled by the responding party, so that the requesting party may inspect, measure, survey, photograph, test, or sample the property or any designated object or operation on it.

(b) Procedure.

(1) Contents of the Request. The request:

(A) must describe with reasonable particularity each item or category of items to be inspected;

(B) must specify a reasonable time, place, and manner for the inspection and for performing the related acts; and

(C) may specify the form or forms in which electronically stored information is to be produced.

(2) Responses and Objections.

(A) Time to Respond. The party to whom the request is directed must respond in writing within 30 days after being served. A shorter or longer time may be stipulated to under Rule 29 or be ordered by the court.

(B) Responding to Each Item. For each item or category, the response must either state that inspection and related activities will be permitted as requested or state an objection to the request, including the reasons.

(C) Objections. An objection to part of a request must specify the part and permit inspection of the rest. 
Because probative evidence in patent infringement cases tends to exist in the form of documents or physical objects, Federal Rule 34 is particularly important to proving and defending patent infringement claims. ${ }^{58}$ While Rule 34 is simplistically known as "documentary discovery," it covers more than just documents. Rather, Rule 34 details the mechanism by which parties may inspect and obtain documents and electronic information, as well as objects or things under another's control or enter upon the premises of another party or non-party. ${ }^{59}$ The obligation to disclose specific documents under a party's control extends far. ${ }^{60}$ For example, in Societe Internationale v. Rogers, the United States Supreme Court held the plaintiff under an obligation to disclose documents to the defendant even though applicable Swiss law forbade this under criminal penalty ${ }^{61}$ The Court deemed the plaintiff in "control" of the requested documents for discovery purposes,${ }^{62}$ because it found the plaintiff in a position to either prompt the Swiss lawmaker to change the criminal statute or create an exception. ${ }^{63}$ Like pre-trial discovery in general, Rule 34 operates extrajudicially and puts the adversaries in the driver's seat. ${ }^{64}$ Broadly speaking, Rule 34 controls the inspection ${ }^{65}$ of two types of property: items ${ }^{66}$ and premises. ${ }^{67}$ First, "items" as used in this thesis

(D) Responding to a Request for Production of Electronically Stored Information. The response may state an objection to a requested form for producing electronically stored information. If the responding party objects to a requested form--or if no form was specified in the request--the party must state the form or forms it intends to use.

(E) Producing the Documents or Electronically Stored Information. Unless otherwise stipulated or ordered by the court, these procedures apply to producing documents or electronically stored information:

(i) A party must produce documents as they are kept in the usual course of business or must organize and label them to correspond to the categories in the request;

(ii) If a request does not specify a form for producing electronically stored information, a party must produce it in a form or forms in which it is ordinarily maintained or in a reasonably usable form or forms; and

(iii) A party need not produce the same electronically stored information in more than one form.

(c) Nonparties. As provided in Rule 45, a nonparty may be compelled to produce documents and tangible things or to permit an inspection. FED. R. CIV. P. 34

58 See Kenneth R. Adamo et al., Document Discovery in Patent Litigation, in PaTENT LiTIGATION STRATEGIES HANDBOOK 2004 CuMULATIVE SuPPlEMENT supra note 1, at 79.

59 FED. R. CIV. P. 34; see JUNKER, supra note 12, at 165 - 66 (criticizing with regard to definitions such as "things" and "property," U.S. law, unlike German law, has failed in providing clear terms.)

60 For example, courts tend to require subsidiaries to produce documents in possession of their parents and vice versa. See e.g. Japan Halon Co. v. Great Lakes Chem. Corp, 155 F.R.D. 626, 627 - 629 (N.D. Ind. 1993).

61 Societe Internationale v. Rogers, 357 U.S. 197, 204 - 206 (1958). Swiss law applied to the requested banking records, because they were controlled by a Swiss affiliate of the Plaintiff and located in Switzerland.

62 Id. at $204-205$.

63 Id. at $205-206$. ("Petitioner is in a most advantageous position to plead with its own sovereign for relaxation of penal laws or for adoption of plans which will at the least achieve a significant measure of compliance with the production order....") (emphasis added). In fact, the Swiss law is an example of a blocking statute discussed in note 334 infra.

64 See Nash v. City of Oakwood, 90 F.R.D. 633, 637 (S.D. Ohio 1981) (stating that the procedures outlined in Rule 34, generally, operate without judicial intervention).

65 The word "inspecting," and its various forms, as used in this paper are meant to include all the activities authorized by Rule 34, that is, measuring, surveying, photographing, testing, and sampling. See FED. R. CIV. P. 34(a)(2).

$66 I d$. at 34(a)(1).

67 Id. at 34(a)(2). 
includes objects, text and other information packaged in both paper and electronic format. ${ }^{68}$ By referring vaguely to "any designated document or electronically stored information" and "any designated tangible things", Rule 34 casts a wide net that expressly includes "writings, drawings, graphs, charts, photographs, sound recordings, images, and other data or data compilations." ${ }^{\prime 9}$ The requesting or receiving party may "inspect, copy, test or sample" such items. ${ }^{70}$

Second, inspection of "premises" covers land or other property under the responding party's control. ${ }^{71}$ Since real property can not be "produced," the Rule requires the responding party to allow the requesting party to enter the property. ${ }^{72}$ As with tangibles, the requesting party or, here, entering party may conduct a series of inspecting activities, which include "measur[ing], survey[ing], photograph[ing], test[ing], or sampl[ing]" the property and the designated objects and operations it hosts. ${ }^{73}$

Rule 34 specifically outlines the procedures for producing documents, electronic information ${ }^{74}$ and permitting entry upon premises. ${ }^{75}$ Requests for such inspections must set forth, individually or categorically, the items sought to be inspected. ${ }^{76}$ The request also must denote a reasonable time, place and manner for the inspection activities and may specify a form for producing electronic information. ${ }^{77}$ Courts have even ordered restoration and production of deleted electronic- or voice-mail messages. ${ }^{78}$ Although the responding party may object to Rule 34 requests, it must provide its reasons for doing so ${ }^{79}$ In Rule 34 's application to patent infringement actions, four areas of particular interest arise.

\section{Inspections of Things - Type of Items Covered}

Rule 34(a)(2) allows the inspecting, sampling and testing of things, including documents and electronically stored information. ${ }^{80}$ The reference to "tangible things" brings almost any type of item within its purview. While a dead body ${ }^{81}$ and fingerprints $^{82}$ were ordered subject to production, discovery in patent infringement cases

68 See id. at 34(a)(1)(A).

$69 I d$. at $34(\mathrm{a})(1)(\mathrm{A})$.

$70 \quad I d$. at 34(a)(1).

71 Id. at 34(a)(2).

72 See id.

73 Id.

74 See id. 34(b)(2)(D)\&(E); e.g. Simon Prop. Group L.P., v. mySimon, Inc. 194 F.R.D. 639 , 640 (S.D. Ind. 2000) (computer records, including deleted ones, are discoverable under Rule 34); see Thomas Y. Allman, The "Two-Tiered" Approach to E-Discovery: Has Rule 26(b)(2)(B) Fulfilled its Promise? 4 RICH J.L. \& TECH. 7 (2008). Further, the Federal Rules of Evidence, like the Federal Rules of Civil Procedure, apply to electronically stored data as they do to other types of evidence. See 5 JACK B. Weinstein \& MARgaret A. Berger, Weinstein's Federal EVIdence § 900.01 (Joseph M. McLaughlin ed., Matthew Bender 2d ed. 2005).

75 FED. R. CIV. P. 34(b).

$76 \quad I d$. at $34(\mathrm{~b})(1)(\mathrm{A})$

77 Id. at 34(b)(1).

78 E.g. Simon Prop. Group L.P., v. mySimon, Inc. 194 F.R.D. at 640 (trademark infringement case where court granted a motion to compel recovery of data from both office and home computers of certain individuals).

79 FED. R. CIV. P. 34(b)(2)(B).

80 FED. R. CIV. P. 34(a)(1)(A); see id. at 34(a) advisory committee's note (2006).

81 Zalatuka v. Metropolitan Life Ins. Co., 108 F.2d 405 (C.A.7 1939).

82 Alford v. Northeast Ins. Co., 102 F.R.D. 99, 101 (N.D. Fla. 1984). 
commonly involves business records, including corporate books and records,${ }^{83}$ photographs,${ }^{84}$ drawings, ${ }^{85}$ bank records, ${ }^{86}$ scientific research data ${ }^{87}$ and lab notebooks. ${ }^{88}$ Any of these items can be relevant and, thus, producible in an infringement action if they are already in existence. ${ }^{89}$

\section{Premise Inspections}

The same relevancy, scope and timing considerations extending to both parties and nonparties that cover document discovery also apply to premise inspections. ${ }^{90}$ Patent infringement litigants tend to make use of premise inspections to scrutinize - mostly by testing, videotaping and photographing - their adversaries' processes and manufacturing facilities. ${ }^{91}$ Experts and consultants often accompany the inspecting party to ensure an efficient performance of the inspection. ${ }^{92}$ Usually the parties collectively plan the parameters of access and inspection..$^{93}$ One practitioner describes the process as follows:

It is usually the technique on such an inspection to attempt to simultaneously conduct a "walking" Rule 30(b)(6) [ ] deposition. This is consistent with [the notice requirement and may include] asking the deponent to recreate certain events on videotape. These "walking" depositions are, however, not easy to do properly and may require an initial or several days of access by the party inspecting to enable full familiarization with the plant, process, and physical constraints applied before commencing the deposition. Often a separate camera for

83 See e.g. Federal Sav. \& Loan Ins. Corp. v. Commonwealth Land Title Ins. Co., 130 F.R.D. 507, 509 (D.D.C. 1990).

84 See e.g. Daniels v. AMTRAK, 110 F.R.D. 160, 161 (S.D.N.Y. 1986).

85 See e.g. Financial Bldg. Consultants, Inc. v. American Druggists Ins. Co., 91 F.R.D. 59, 60 (N.D. Ga. 1981).

86 See e.g. Societe Internationale v. Rogers, 357 U.S. 197, 204 - 206 (1958); contra Duracell Inc. v. SW Consultants, Inc. 126 F.R.D. 576, 579 (1989) (stating that discovery of research and development information, financial statements, bank accounts and records, net profits and losses, investments was especially sensitive for a company in a vulnerable competitive position and, thus, merited a protective order under Rule 26(c)(1)(G)).

87 See e.g. Simon v. G.D. Searle \& Co., 119 F.R.D. 680, 681 (D. Minn. 1987).

88 Fresenius Med. Care Holding Inc., v. Baxter Int'l, Inc., 224 F.R.D. 644, 649 (2004); E.I. Du Pont de Nemours v. Phillips Petroleum Co. 24 F.R.D. 416, $424-425$ (2006). However, in deciding whether to permit production of laboratory notebooks and record courts ask how important those records are to the case. Id.

897 James Wm. Moore et al., Moore's Federal Practice \$34.12[2] (Matthew Bender 3d ed. 2008). This means that the producing party has no obligation to create or draft new documents solely for Rule 34 discovery. E.g. Alexander v. FBI, 194 F.R.D. 305, 310 (D.D.C. 2000). However, a defendant in a defamation case was ordered to create and produce handwritten exemplars. In doing so, the judge construed Rule 34 broadly in conjunction with Rule 26(b) and referred to the common occurrence during depositions of compelling deponents to make a sketch in accident cases. Harris v. AtholRoyalston Reg'l Sch. Dist. Comm., 200 F.R.D. 18, 20 (D. Mass. 2001).

90 See FED. R. CIV. P. 34; FED. R. CIV. P. 45.

91 E.g. Micro Chem., Inc. v. Lextron, Inc., 193 F.R.D. 667, 670 (D. Colo. 2000); see Kenneth R. Adamo et al., Document Discovery in Patent Litigation, in PATENT Litigation STRATEGIES HANDBOOK 2004 CUMULATIVE SUPPLEMENT supra note 89, at 79, $104-105$.

92 E.g. Eirhart v. Libbey-Owens-Ford Co., 93 F.R.D. 370, 372 (N.D. Ill. 1981) (access to plant by plaintiffs, their counsel and consultants).

93 Kenneth R. Adamo et al., Document Discovery in Patent Litigation, in PATENT Litigation StRateGIES HANDBOOK 2004 CUMULATIVE SUPPLEMENT supra note 1, at 79, 104; e.g. National Dairy Prods. Corp. v. L.D. Schreiber \& Co., 61 F.D.R. 581, 583 (E.D. Wisc. 1973) (performance of tests only in presence of opponent's counsel and experts). 
the deposition videotape is advisable with a primary camera focused on taking the inspection/testing videotape. ${ }^{94}$

To alleviate burdensomeness and disruption and create mutually agreeable circumstances, ${ }^{95}$ parties commonly collaborate in specifying the location, time and manner of the inspection. ${ }^{96}$ However, courts do intervene. For example, when production sought under Rule 34(a) is so voluminous that it would impose oppressive copying and transportation costs on the producing party, courts may order inspection of the records at the producing party's convenience and place of business, rather than hardcopy-production. ${ }^{97}$

\section{Custody, Possession, Control}

Rule 34 authorizes inspection of things and premises if they are within either the "possession, custody, or control" 98 of a party or proper nonparty. ${ }^{99}$ Accordingly, courts do not require the preparation of nonexistent writings producible for inspection. ${ }^{100}$ Still, the concept of "custody, possession or control" is far-reaching, because only one of the three need apply and "control" is broadly construed under Rule $34 ;{ }^{101}$ it may include having a legal right to obtain a document, even if no copy is presently possessed. ${ }^{102}$ At least one commentator argues and several courts have held that the concept of control should extend to circumstances when a "practical ability to obtain materials in possession of another" exists, even absent a legally enforceable right to obtain the documents. ${ }^{103}$

In patent infringement actions, issues of control surface when nonparty agents, such as attorneys, corporate officers and corporate parents and their subsidiaries possess,

94 Kenneth R. Adamo et al., Document Discovery in Patent Litigation, in PATENT LiTIGATION STRATEGIES HANDBOOK 2004 CUMULATIVE SuPPLEMENT supra note 1, at 79, 105 (footnotes omitted).

95 See Harris v. Sunset Oil Co., 2 F.R.D. 93, 93 (W.D. Wash. 1941) (ordering production's location and time or, alternatively, allowing parties to agree on a mutually agreeable time and place).

96 See 7 MOORE ET AL., supra note 89, at \$34.14[3].

97 See id.; e.g. Baine v. General Motors Corp., 141 F.R.D. 328, 331 - 32 (M.D. Ala. 1991) (inspection of accident reports at their usual storage location to reduce time and expense).

98 FED. R. CIV. P. 45(a) (emphasis added). The disjunctive listing implies that only a single requirement must apply.

99 Nonparties must be subject to jurisdiction under Federal Rule 45.

1007 MOORE ET AL., supra note 89, at \$34.14[2][a]. Nevertheless, creation of a computer tape which did not previously exist was proper under Rule 34. In re Air Crash Disaster at Detroit Metro. Airport, 130 F.R.D. 641, 646 (E.D. Mich. 1989).

1017 MoORE ET AL., supra note 89, at \$34.14[1]. See also Societe Internationale v. Rogers, 357 U.S. at 204 - 206, supra notes 61 - 63 (holding that Roger's factual and legal background mandated Rule 34 to be construed in accordance with the Trading with the Enemy Act's policies and that so read a ruling that the documents were in the plaintiff's "control" sufficient to require Rule 34 production was justified).

102 Scott v. Arex, Inc., 124 F.R.D. 39, 41 (D. Conn. 1989) (control means the right, authority or ability to obtain document on demand); contra Chaveriat v. Williams Pipe Line Co., 11 F.3d 1420, 1426 - 1427 (7th Cir. 1993) (fact that party could theoretically and only with great efforts obtain a document does not mean it has control).

103 See 7 MoORE ET AL., supra note 89, at \$34.14[2][b]; e.g. Riddell Sports Inc. v. Brooks, 158 F.R.D. 555,558 - 559 (S.D.N.Y. 1994) (emphasis added) (ordering corporation to produce tapes made by its officer and in possession of his attorney, because control exists if the party has the practical ability to obtain the tapes). 
control or have custody of discoverable evidence. Documents in the possession of such legal persons are, generally, deemed within their corporation's control and, thus, discoverable if non-privileged. ${ }^{104}$ This extended and inferred concept of control also covers parent-subsidiary relationships, even if the companies operate in different countries. ${ }^{105}$ While the specific corporate form of the companies' relationship does not dispose of the control issue, courts tend to rely on multi-factor tests in assessing whether, overall, the entities have a sufficiently close nexus to justify a finding of control. $^{106}$

\section{Obligation to Preserve and Spoliation}

Until service of process, no general obligation exists to preserve information for potential discovery production. ${ }^{107}$ Nevertheless, spoliation, a discovery violation, is defined as the "intentional destruction, mutilation, alteration, or concealment of evidence" 108 in "pending or reasonable foreseeable litigation." ${ }^{109}$ Exactly when litigation may be deemed "reasonably foreseeable" remains unclear. ${ }^{110}$ Thus, while receipt of a warning letter or other notice regarding the possibility of subsequent litigation does not necessarily effect an obligation to preserve likely evidence, courts may construe such acts as sufficient to impose preservation obligations or to permit an adverse inference instruction based on destruction of evidence. ${ }^{111}$ Subjective apprehension seems to play an important role in whether document destruction contravenes Rule 26.

\section{B. Context of Rule 34 amid Other Discovery Rules}

As mentioned above, Rule 26 constitutes an umbrella rule detailing the general parameters of discovery. ${ }^{112}$ It allows the parties to discover any nonprivileged matter relevant to a party's claim or defense, "including the existence, description, nature, custody, condition and location of any books, documents or other tangible things." 113 Thus, discoverability extends not only to admissible evidence but also to matter that

104 See American Soc'y for Prevention of Cruelty to Animals v. Ringling Bros. and Barnum \& Bailey Circus, 233 F.R.D. 209, 212 (D.D.C. 2006) (documents gathered and possessed by attorney are within client's control, but nondiscoverable as work product); see General Envtl. Sci. Corp. v. Horsfall, 136 F.R.D. 130, 134 (N.D. Ohio 1991) (individual defendants who are corporate officers, directors and shareholders must produce documents possessed by corporation).

105 Japan Halon Co. v. Great Lakes Chem. Corp., 155 F.R.D. 626, 627 - 29 (N.D. Ind. 1993).

106 Uniden America Corp. v. Ericsson, Inc., 181 F.R.D. 302, 306 (M.D.N.C. 1998) (applying five-factor test to determine control).

107 E.g. Hansen v. Dean Witter Reynolds Inc., 887 F. Supp. 669, 675 - 76 (S.D.N.Y. 1995).

108 BLACK's LAW DiCTIONARY POCKET EDITION 659 (2d ed. 2004)

109 See West v. Goodyear Tire \& Rubber Co., 167 F.3d 776, 779 (2d. Cir. 1999).

110 See Kenneth R. Adamo et al., Document Discovery in Patent Litigation, in Patent Litigation STRATEGIES HANDBOOK 2004 CUMULATIVE SUPPLEMENT supra note 1, at 79, $96-7$.

111 See Rush v. Artuz, 00 Civ. 3436, 2003 U.S. Dist. LEXIS 7158, at *6 (SD.N.Y. Apr. 3, 2003).

112 See supra Part II.

113 FED. R. CIV. P. 26(b)(1). 
may reasonably lead to finding admissible evidence. ${ }^{114}$ The availability or previous delivery of the same information contained in the requested documents also do not directly bar document discovery. ${ }^{115}$ Rule 26(b)(1) authorizes discovery of information about infringement, non-infringement, and a disputed patent's scope, because those issues go to the very heart of the liability question in patent infringement actions. ${ }^{116}$ That rule entitles both patent owners and alleged infringers to discover relevant and detailed information regarding an adversary's contentions about the infringement. ${ }^{117}$ For example, a defendant in an infringement suit can discover information from the plaintiff concerning the latter's interpretation of the patent claims and their scope. ${ }^{118}$ Both parties may also discover information relevant to claims of noninfringement. ${ }^{119}$ In V.D. Anderson Co. v. Helena Cotton Oil Co., ${ }^{120}$ for example, the court held discovery requests inquiring about the patent proprietor's knowledge of the defendant's operation and products permissible, because responses to them could constitute admissions by the patent owner concerning the defendant's actual infringement of the patent-in-suit.

\section{Privileges}

Rule 26 governs the scope of Rule 34. A party can object to a production or inspection request based the application existence of a privilege. ${ }^{121}$ Privileged and, thus, nondiscoverable matter in patent infringement cases includes only information that qualifies under a federal common law privilege. ${ }^{122}$ No absolute privilege exists for patents or confidential research and development. ${ }^{123}$ In patent litigation, the attorney-client priv-

114 FED. R. CIV. P. 26(b)(1). Subject to court authorization all nonprivileged matters relevant to the case are discoverable. Rule 26(b)(1) defines the scope of discovery as follows: "Parties may obtain discovery regarding any matter, not privileged that is relevant to the claim or defense of any party, including the existence, description, nature, custody, condition, and location of any books, documents, or other tangible things and the identity and location of persons having knowledge of any discoverable matter. For good cause, the court may order discovery of any matter relevant to the subject matter involved in the action. Relevant information need not be admissible at the trial if discovery appears reasonably calculated to lead to the discovery of admissible evidence." Id. (emphasis added); see e.g. Financial Bldg. Consultants, Inc. v. American Druggists Ins. Co., 91 F.R.D. 59, 61 (N.D. Ga 1981) ("what is relevant during pretrial discovery and what is admissible during trial are two different things, the former being broader than the latter.")

1157 MOORE ET AL., supra note 89, at \$34.12[5][a].

1166 MOORE ET AL., supra note 13, at \$26.46[12][a].

$117 I d$.

118 Digitraonics Corp. v. Jewel Cos., 57 F.R.D. 649, 649 - 650 (N.D. Ill. 1972) (patentee's explanation of how each piece of prior art cited to the patent examiner during prosecuting at the United States Patent and Trademark Office relates to each element of each allegedly infringed claim relevant to the issue of the claims' scope and, thus, to infringement).

1196 MoORE ET AL., supra note 13, at \$26.46[12][a]; see e.g. Nat'l Dairy Prod. Corp. v. L. D. Schreiber \& Co., 61 F.R.D. 581, 582 (E.D. Wis. 1973) (authorizing defendant to inspect patent proprietor's plant, because doing so could reveal the latter's failure to practice the patented invention. Such lack of patent practice would result in a narrow construction of the claims and, thus, increase the probability that the defendant is not infringing.

120117 F.Supp. 932 (E.D. Ark. 1953).

121 See FED. R. CIV. P. 26(b)(1) (permitting discovery as to “any nonprivileged matter").

122 This is so because patent law lies within the province of federal law. See U.S. Const. art. I, $\S 8$, cl. 8.

123 See Stephen C. Bruner, Discovery: An Ordered Approach, 30 FEDERATION Ins. Coun. Q. 205,247 (1980); see 6 MOORE ET AL., supra note 13, $\$ 26.48$ - 52 (listing a litany of federal and trade privileges). However, a "protective order" may prevent disclosure of "trade secrets or other confidential 
ilege and work product doctrine are the most commonly used mechanisms in attempting to protect sensitive communications from document discovery. ${ }^{124}$

The attorney-client privilege applies to communications between lawyers and their clients when lawyers act in counseling or litigating roles. ${ }^{125}$ In the patent context, the Court of Appeals for the Federal Circuit has held that the attorney-client privilege protects invention records prepared and submitted to counsel ${ }^{126}$ primarily for obtaining legal advice concerning patent applications or assistance in a legal proceeding, even if this invention record contains technical and not strictly juridical information. ${ }^{127}$ The work-product doctrine protects documents prepared in anticipation of litigation or trial from disclosure. ${ }^{128}$ Because they likely contain crucial analyses and strategies of the litigation, these communications threaten to be damaging in the adversaries' hands. ${ }^{129}$

\section{Protective Orders}

Protective orders aim to ensure that discovery proceeds efficiently and fairly by injecting judicial supervision into especially sensitive matters where cooperation among the parties' has failed. ${ }^{130}$ While Rule 26(c)(1) lists eight ways of achieving this, its non-exhaustive nature allows much judicial discretion in fashioning protective orders. ${ }^{131}$ However, motions for protective orders should be used sparingly, because courts generally dislike extensive involvement in discovery disputes. ${ }^{132}$ For example,

research, development or commercial information.” FED. R. CIV. P. 26(c)(1)(G); see also Coca-Cola Bottling Co. of Shreveport, Inc. v. Coca-Cola Co., 110 F.R.D. 363, 366 (D.Del. 1986) (when CocaCola Co. refused to comply with the court's request to disclose its recipe for making Cola, which was held essential to the determining the dispute, all inferences related to the recipe were drawn in favor of the opposing party); see 23 CHARLES Alan Wright ET AL., FEDERAL PRACTICE AND PROCEDURE $\S 5422$ (2d ed. 2008) (discussing policies underlying privileges and Federal Rule of Evidence 501).

124 See Kimberly A. MoOre, PAul R. Michel \& RAPHAEL V. Lupo, PATENT Litigation AND STRATEGY 145, 164 - 165 (2nd ed. 2003); see FED. R. CIV. P. 26(b)(3)-(4). Other privileges such as the priest-penitent, physician-patient and governmental privileges are virtually irrelevant to patent actions and, thus, beyond the scope of this paper. See e.g. 6 MOORE ET AL., supra note 13, at $\$ 26.48-52$.

125 U.S. v. Chen, 99 F.3d 1495 (9th Cir. 1996).

126 That case concerned corporate in-house counsel for Spalding and, more specifically, its "patent committee" consisting presumptively of both lawyers and patent agents. See In re Spalding Sports Woldwide, 203 F.3d 800, 805 (Fed. Cir. 2000).

127 In re Spalding Sports Woldwide, 203 F.3d at $805-806$ (justifying that "an attorney cannot evaluate patentability or prepare a competent patent application without knowing the prior art and obtaining relevant technical information from the inventors. "), quoting Sperry v. Florida, 373 U.S. 379,383 (1963) ("[T]he preparation and prosecution of patent application of others constitutes the practice of law.")

128 The work product doctrine and attorney-client privilege constitute independent concepts. While the former protects the adversarial system by assuring that an attorney's files normally remain private and protected from interferences and parasitism by the opposing party, the latter is designed to encourage frank and complete communication between attorneys and their clients. See Christina M. Tchen et al., The Attorney-Client Privilege and Work-Product Doctrine in Internal Investigations: Protecting the Privilege: What Is It, Who Has It, and What Happens If You Waive It Good-Bye? 778 PLI/LIT 33 (2008); Alvin K. Hellerstein, A Comparative Survey of the Attorney-Client Privilege and Work-Product Doctrine, 540 PLI/LIT 589 (1996); see also 6 MOORE ET AL., supra note 13, at §26.70[8] (distinguishing work product doctrine and attorney-client privilege).

129 MOORE, MiCHEL \& LUPO, supra note 124 , at 145.

130 Id. at 162.

131 FED. R. CIV. P. 26(c)(1) (including an order different from what the parties sought)

132 Raphael V. Lupo, Protective Orders, in PATENT Litigation STRATEGIES HANDBOOK 125, 133 (Barry L. Grossman \& Gary M. Hoffman eds., BNA Books 2002). 
a movant's obligation to first attempt to settle the dispute amicably and show "good cause" eliminates the availability of protective orders for purely tactical purposes. ${ }^{133}$

\section{Motions to Compel and Sanctions}

A party who has made a Rule 34 request and, in response, received an objection or no answer at all may seek an order compelling compliance under Federal Rule 37(a). ${ }^{134}$ Once the court enters such an order, Rule 37(b) provides various sanctions if the order is violated. ${ }^{135}$ There are two main reasons for issuing sanctions involving Rule 34; noncompliance with a proper request and improper destruction of documents. ${ }^{136}$ Overproduction or dumping of documents falls under the former and constitutes a common problem concerning Rule 34 discovery. ${ }^{137}$ For example, in Levene v. City of New York, the court sanctioned the plaintiff by dismissing his claims entirely for "dumping" more than 10,000 pages on the defendants, in addition to other failures to comply with discovery orders. ${ }^{138}$ Courts exercise much discretion regarding what type of sanction to issue and do so on a fact-specific basis. ${ }^{139}$

133 See FeD. R. CIv. P. 26(c)(1)(G); see also Nestle Foods Corp. v. Aetna Casualty \& Surety Co., 129 F.R.D. 483, 486 (D.N.J. 1990) (non-patent case denying protection order because movants failed to attempt to negotiate or move for protective order in a timely fashion).

1347 MOORE ET AL., supra note 89, at \$34.16[2].

135 See FED. R. CIV. P. 37(b).

136 See 7 MoORE ET AL., supra note 89, at \$34.16[3],[4]. Sanctions for destruction of documents may be imposed pursuant to Rule 37(b) only if the destruction happened after being served with a Rule 34 request. A court may exercise its "inherent power" to sanction abusive acts involving pre-request destruction, if the destructing party was reasonably aware that the items it was destroying constituted evidence. Id.; e.g. Alliance of End Repression v. Rochford, 75 F.R.D. 438, 440 (N.D. Ill. 1976) (sanctions imposed when documents required to answer interrogatories were destroyed after defendants learned that plaintiffs were about to sue).

13797 Civ. 7985, 1999 U.S. Dist. LEXIS 9031 (S.D.N.Y. June 11, 1999).

138 Id. at $* 9$.

139 See 7 MOORE ET AL., supra note 89, at \$34.16[3]-[4]. 
The French Intellectual Property Code (Code de la propriété intellectuelle) (CPI) governs the process of evidence-gathering known as Saisie-contefaçon ${ }^{140}$ in patent infringement lawsuits in France. The Saisie is strictly regulated and is anything but broad. This narrowness springs from at least five conditions. First, the Saisie is reserved exclusively for intellectual property infringement actions. It is worth noting, however, that separate provisions authorizing saisies, in substantially the same form, for other intellectual property rights exist elsewhere in the CPI. ${ }^{141}$ Second, a Saisie can only be conducted on the basis of a French patent ${ }^{142}$ or a European patent designating France. ${ }^{143}$ Third, the Saisie, as an extraordinary measure, proceeds under the strict control of the judiciary, the officials of which authorize, carry out and review the process. ${ }^{144}$ Fourth, only patentholders or their exclusive licensees may initiate a Saisie. ${ }^{145}$ Fifth, the subject matter subject to a Saisie is limited to the evidence that the judge ordered and which relates to proving infringement of a specific patent. ${ }^{146}$

France has a typical civil law legal system, characterized by codified laws, judgecontrolled litigation, ${ }^{147}$ continually progressing hearings, no juries and, most importantly, the absence of discovery. ${ }^{148}$ It also boasts a long-standing tradition of protecting patents under a natural rights theory. ${ }^{149}$ In fact, France passed its first modern patent law as early as $1791 .{ }^{150}$ While that version of the law did not explicitly authorize a Saisie, courts interpreted the rights to a patent as incorporating the confiscation

140 Literally, this means "seizure-infringement" or "infringement seizure."

141 Saisie measures as applied to copyrights, computer rights, trademarks, and patents are codified at Art. L 332-1, Art. L 332-4, Art. L 716-7, Art. L 615-5 CPI, respectively.

142 It must be noted, however, that Saisies are available for granted patents and also for pending French applications. See Art. R 615-2 CPI.

143 Art. L 614-9 CPI. Note that any patent or patent application must have an available French translation in order to confer rights to a Saisie. $I d$.

144 See Art. L 615-5 CPI; see Art. R 615-2 CPI; see Art. R 615-4 CPI.

145 Art. R 615-2, $12-3$ CPI.

146 See infra Part III, A.

147 French judges, like those in other civil law countries, are career-judges. Cathrine Elliott \& Cathrine Vernon, The French Legal System (2000), reprinted in CIVIL LiTIGATION IN COMPARATIVE CONTEXT, 192 - 201, at 76 - 82 (Oscar G. Chase \& Helen Hershkoff eds., Thompson/West 2007). See JUNKER, supra note 12, at 84 - 86 (comparing U.S. and German federal judges).

148 See CHASE ET AL., supra note 12, at 4-15 (identifying the basic elements of civil law procedure, by explaining German, French and Italian procedure, and comparing them with the common law model).

149 The French Patent Act of 1791 reflects the natural rights theory of intellectual property, which deems the right to an invention as a natural and personal right independent of any government-granted a privileges. SubCOMM. ON PATENTS, TRADEMARKS, \& COPYRIGHTS OF THE S. COMM. ON THE JUDICIARY, 85Th Cong., An ECONOMIC REviEW OF the PATENT System, at 44 (Comm. Print 1958) (prepared by Fritz Machlup).

150 Philippe Mueller, Ex Parte Search Orders for Securing Evidence of Infringement: Implementation Process of Directive 2004/48/EC of the European Parliament and of the Council of 29 April 204 on the Enforcement of Intellectual Property Rights, MAS-IP Diploma Papers \& Research Reports Paper 26, 17 (2005), available at http://www.bepress.com/ndsip/papers/art26. 
of infringing articles for subsequent use at trial. ${ }^{151}$ In 1844, this construction was codified. ${ }^{152}$

The Saisie's popularity in France is unquestionable. Virtually all patent infringement suits debut with a Saisie. ${ }^{153}$ Conventional wisdom in patent litigation practice has it that a Saisie benefits even rightholders who already have sufficient evidence of infringement. ${ }^{154}$ French law deems the right to a Saisie as inherent in the patent itself. ${ }^{155}$ This right, as most rights, can be waived. ${ }^{156}$ Further, the Saisie merely enables pre-litigation fact-gathering that will, in an ensuing lawsuit, help to prove patent infringement. Thus, it is not aimed to provide the rightholder with a preliminary injunction. ${ }^{157}$

The Saisie unfolds itself in what may be distinguished as three separate phases; the request for the Saisie order, the performance of the Saisie, and then, the filing requirement and appeal option. The following sections explain the Saisie by way of this chronological unraveling.

\section{A. Before the Saisie: Ex-Parte Application for Inspection}

The Saisie doubtlessly appeals to plaintiffs due to its relative simplicity and low cost. ${ }^{158}$ The process of applying for a Saisie order that a rightholder must undergo is notably effortless and streamlined. ${ }^{159}$ A rightholder suspecting infringement of his patent may request the president of a district court (tribunal de grande instance) ${ }^{160}$ of the place of the presumed infringement to authorize a Saisie of an expected infringer or any third party with potentially relevant information. ${ }^{161}$ However, the jurisdiction to authorize a Saisie is separate from that of adjudicating infringement cases. Thus, the president of the district court issuing the Saisie order is not necessarily from the same court subsequently adjudicating the infringement action. ${ }^{162}$ In total, 168 district courts exist across France, which makes it relatively convenient to file a Saisie

151 Id.

$152 \mathrm{Id}$.

153 See e.g. Boval, Sicherungs- und einstweilige Maßnahmen im Zusammenhang mit Patentverletzungsklagen in Frankreich, GRUR INT. 1993, 377 - 378.

154 E.g. Jochen Bühling, Frieger Mes \& Graf v der Groeber, Obtaining Evidence When Preparing Patent Litigation, available at http://www.buildingipvalue.com/06EU/172_175.htm. ("Even when there is already sufficient evidence, clients are often advised to obtain additional evidence in order to obtain an official statement of a court-appointed expert that can be used in court.")

155 Philippe Mueller, supra note 150, at 17.

156 Art. L 615-5 CPI ("Infringement can be proven by any means whatsoever") (translation by the author).

157 Bizollon, et AL., Saisie-Contrefacon 2 (Véron ed., Dalloz 2d ed. 2005); see Art. L 615-5 CPI (addressing the aim of finding evidence but making no mention of preliminary injunctions).

158 In fact, plaintiffs' attorneys authored most of the literature available on the Saisie. They tend to praise the procedure as a powerful, quick, and cheap investigation tool. See Pierre Véron, The "Saisie-Contrefacon": An Overview, 139. (Véron I).

159 See Simon Cohen \& Martin Kohler, Disclosures in European Patent Litigation: Towards an Efficient Protection of Patent Owners, IP LiTIGATOR (March 1,2005), available at http://www.accessmylibrary.com.

160 See Art. D 631-2 CPI

161 Art. L 615-5 CPI.

162 BIZOLLON ET AL., supra note 157, at 32. 
request. ${ }^{163}$ In doing so, the applicant must only show two things: ownership of a valid patent right and a subjective apprehension of its infringement. ${ }^{164}$ The patent right which may constitute the basis of a Saisie must be either a national French patent ${ }^{165}$ or a French-part of a European patent. ${ }^{166}$ Further, it can be an issued and not-yet expired patent or a still-pending application. ${ }^{167}$

The plaintiff's attorney files a petition defining the precise scope of the requested inspection. ${ }^{168}$ This petition, typically, requests that certain persons be allowed to participate in the Saisie and that particular acts be performed. ${ }^{169}$ Concurrently, the attorney files a draft order reflecting the above conditions. ${ }^{170}$ If the requirements of a valid patent right and apprehension of infringement are met, a court must permit the Saisie, although it may limit it so as to prevent spying as well as useless and harassing acts. ${ }^{171}$ Accordingly, if the draft order conforms to the standard form, the judge, after having reviewed it, usually signs it without changes. ${ }^{172}$

The president issuing the Saisie does not examine the merits of the alleged infringement or assess the validity or probability of the rightholder's assertions. ${ }^{173}$ This rather cursory pro forma review roots itself in the understanding that a Saisie constitutes an inherent right of the patentholder. ${ }^{174}$ The applicant also need not show evidence of infringement, because it is the very purpose of a Saisie to generate such evidence. ${ }^{175}$ Nevertheless, the judge has discretion to require the posting of a bond if that appears necessary to protect the defendant from abuse and damages which the seizing party may cause. ${ }^{176}$

Most importantly, the Saisie's force springs from its ex parte nature. ${ }^{177}$ While the plaintiff applies for and is granted the Saisie, no others are notified. ${ }^{178}$ This aims to maximize the defendant's surprise and prevent him from hiding evidence of infringement. Thus, the Saisie's application process gives the defendant no right to voice his stance or make out a defense; he is typically notified of the Saisie only when the bailiff

163 While a Saisie may be requested in 168 fora, only 10 courts have jurisdiction to hear patent infringement cases.

164 Art. R 615-2, 2 CPI.

165 Meaning one issued by the French patent office. Interestingly, the French patent office does not conduct substantive examinations.

166 At this point it is worth noting that a European patent, granted by the European Patent Office (EPO), constitutes a bundle of national rights. That is, the EPO conducts a substantive examination of the patent application, but upon issuance the patent becomes a series of purely national rights in the countries designated in the application. Accordingly, the patent can be revoked in one country but remain in force in another. Moreover, the granted patent is subject to national law concerning both substance and procedure.

167 Art. R 615-2, 92 CPI.

168 Véron I, supra note 157, at 136.

$169 \mathrm{Id}$.

$170 \mathrm{Id}$.

171 CA Aix-en-Provence, $1^{\text {er }}$ déc. 1976, PIBD 1977, nº 186, III, 63, et Ann. propr. ind. 1978, 293.

172 Id.

173 See Art. R 615-2 CPI; Philippe Mueller, supra note 150, at 29 ("The judge has no right to assess the degree of probability of infringement.").

174 Véron I, supra note 157, at 136. "The holder of a valid right is entitled to obtain a Court order autho175 Id. rizing the saisie") (emphasis added).

176 Bizollon ET AL., supra note 157, at $43-44$.

177 Véron I, supra note 157, at 136.

178 Philippe Mueller, supra note 150, at 17. 
pounds on his door in order to perform the inspection. ${ }^{179}$ Although the seized party may appeal the decision to grant a Saisie, such an appeal lacks suspensive effect. ${ }^{180}$ Thus, the seized party has virtually no means to legally prevent the Saisie. ${ }^{181}$

While being granted a Saisie is markedly simple for the rightholder, drafting an effective request, which hopefully will become the basis for an order, may prove more challenging. ${ }^{182}$ This is so because the Saisie, in contrast to discovery, does not require the parties to cooperate. Put differently, the defendant need not actively support his adversaries' search for evidence. ${ }^{183}$ Thus, while the Saisie order grants access to inspect and search the defendant's premises, within the limits set out in the order, such admittance does not make relevant evidence magically appear. Instead, the rightholder must know where to search for evidence of possible infringement and specify so in the request. This task is not simple. After all, the parties are probably competitors and, thus, are unlikely to visit each other regularly so as to have some familiarity with the other's premises and operations. ${ }^{184}$

\section{B. During the Saisie: Carrying out the Order}

In theory, the bailiff (huissier de justice) is the only person essential to execute a Saisie. ${ }^{185}$ He performs the inspection by way of documenting information and gathering items while others, if present, merely assist. ${ }^{186}$ Although the rightholder may choose the bailiff, ${ }^{187}$ the bailiff is a public official who acts on behalf of the court. The United States' legal system does not engage a comparable judicial officer. While the bailiff is absolutely essential to performing a Saisie, he has little discretion regarding evidence. ${ }^{188}$ This is because the order spells out precisely what he must do. ${ }^{189}$ If his actions exceed what the order permits, the Saisie is susceptible to annulment later on. ${ }^{190}$

In practice, a team of technical experts, police and others depending on the demands of the case, accompany the bailiff. ${ }^{191}$ Those persons often prove especially vital to the Saisie's success, because the seized party has little obligation to assist the bailiff in locating evidence and the bailiff tends to be unfamiliar with the specific infringement at hand. The rightholder also has a right to select the experts, although he may not

179 Véron I, supra note 157, at 136.

180 Cohen \& Kohler, supra note 159.

181 Id.

$182 \mathrm{Id}$. ("The real trouble for the patentee might start once the saisie-contrefacon is granted and [...] the search for evidence is launched at the place of the defendant.")

183 Id

184 See id.

185 See Art. L 615-5 CPI.

186 See Véron I, supra note 157, at 137.

187 Art. L 615-5 CPI; BIZOLLON ET AL., supra note 157, at 35 - 36 (stating that the plaintiff must not mention the bailiff by name, but can refer to any bailiff authorized to practice in the court's jurisdiction.)

188 BIZOLLON ET AL., supra note 157, at 43.

$189 \mathrm{Id}$.

190 See id.

191 Id. at 36-37. 
simply pick his own employees. ${ }^{192}$ Nevertheless, a righholder's patent attorney was held neutral and permitted to advise a Saisie. ${ }^{193}$ The experts are, typically, skilled in the domain of the patent and, thus, can efficiently locate evidence of infringement. ${ }^{194}$ A police officer, and in some cases ${ }^{195}$ an entire police squad, may assist the bailiff in gaining access and preventing an opposition by the seized party. ${ }^{196}$ More generally, any person having useful technical skills may assist in the Saisie. ${ }^{197}$ Thus, sometimes photographers, accountants and computer experts accompany the bailiff. ${ }^{198}$

While the legislative texts on the Saisie do not expressly forbid the seizing party's participation during the Saisie, most orders now mandate that the seizing party or his employees may not be present. This exclusion of the plaintiff and others closely linked to him roots itself in the French Supreme Court's (La Cour de cassation) interpretation of Article 6.1 of the European Convention on Human Rights. ${ }^{199}$ Article 6.1 ensures everyone a fair civil trial and allows exclusion of the public "in the interest of morals, ... the protection of the private life of the parties ..., or to the extent strictly necessary in the opinion of the court in special circumstances where publicity would prejudice the interests of justice." ${ }^{200}$ Further, this rule contemplates the inherent risk the presence of the plaintiff or his affiliates poses to the seized party's trade and commercial secrets. ${ }^{201}$ Given the patentee's likely absence during the Saisie' performance, it is crucial to prepare ahead of time by carefully drafting detailed yet flexible instructions for the bailiff and experts to follow. ${ }^{202}$ Those instructions should direct the bailiff as to what notes to take and information or processes to pay particular attention to while, concurrently, providing coaching as to the collection of items. ${ }^{203}$

Two different types of Saisies exist: The saisie descriptive and the saisie reele. ${ }^{204}$ The saisie descriptive consists of the bailiff taking notes and describing infringing pro-

192 Art. L 615-5 CPI; BIZOLLON ET AL., supra note 157, at 36. (stating that "any expert of the requesting party's choice" should be permitted as long as that expert is independent.) (emphasis added) (translation by the author).

193 TGI Paris, $3^{\mathrm{e}}$ ch., $2^{\mathrm{e}}$ sect., 12 oct. 2001, RD propr. int. 2002, $\mathrm{n}^{\mathrm{o}} 136$, p. 34 - TGI Paris, $3^{\mathrm{e}}$ ch., $2^{\mathrm{e}}$ sect., 23 déc. 2002, Propr. industr. 2003, comm. $\mathrm{n}^{\circ} 58$.

194 Véron I, supra note 157, at 137.

195 A squad is more common for piracy than for run-of-the-mill patent cases, however. See id.

196 Id. The bailiff may employ police force when necessary, even if the order does not expressly mention such force. TGI Paris, $3^{\mathrm{e}}$ ch., 29 mai 1987, RIPIA 1987, 180.

197 Véron I, supra note 157, at 137.

198 Id. Note, that those persons, too, must be mentioned in the order. See BIZOLLON ET AL., supra note 157 , at 35. (instructing, however, that "[t]he request can restrict itself to the categories of persons" and that specifically naming individuals may create difficulties when those persons later turn out to be unavailable). Id. (emphasis added) (translation by the author).

199 Cass. com., 26 avr. 2004, $\mathrm{n}^{\circ}$ 02-20.330, D. 2004, AJ, p. 1671. Prior to this ruling, courts had sometimes authorized the presence of plaintiffs or their employees, especially in cases concerning models and designs. See CA Paris, $4^{\mathrm{e}}$ ch., 14 mars 1991, RD propr. ind. 1991, nº 34, 20, PIBD 1991, nº 506, III, 500 .

200 Convention for the Protection of Human Rights and Fundamental Freedoms, art. 6(1), Nov. 4, 1950, 213 U.N.T.S. 222.

201 This risk is naturally greater when the Saisie occurs on the seized party's premises rather than at a public trade show. BIZOLLON ET AL., supra note 157, at 37.

202 Cohen \& Kohler, supra note 159.

203 See id.

204 BIZOLLON ET AL., supra note 157, at 38. 
cesses, products or devices on paper which the plaintiff had previously indicated in the request. ${ }^{205}$ Depending on the subject matter of the patent, this usually concerns a product, such as a machine, apparatus, system, device, instrument, or an arrangement of chemical products, or a process in the form of an operating style, a manufacturing, treatment or working process. ${ }^{206}$ Those described items and processes remain in the seized party's possession who may freely dispose of them. ${ }^{207}$ In practice, it is common for the bailiff to simply write down what the expert says when describing evidence. ${ }^{208}$ In case of complex processes or machines, the bailiff may request to have the machine run, opened or otherwise operated so as to discern how it functions. ${ }^{209}$ Further, the bailiff may formulate his own questions in order to assist him in procuring evidence. ${ }^{210}$ Thus, he can question the seized party's personnel, but he must also record the explanations and protests of the seized person regarding the alleged infringement. ${ }^{211}$ Nevertheless, the bailiff lacks any investigative or interrogational powers. $^{212}$

The saisie reélle constitutes the actual taking away of allegedly infringing copies and samples. ${ }^{213}$ In product patent cases, this allows the bailiff to gather products covered by the patent ${ }^{214}$ and, in process patent actions, the products made by the process since those are equally covered by the patent. ${ }^{215}$ However, the consent to remove samples does not extend to the entire stock of the infringing products; a limitation which underpins the Saisie's basic purpose as a tool for gathering and preserving evidence and as not a preliminary injunction. ${ }^{216}$ In fact, the plaintiff must detail when requesting the Saisie how many samples he would like to see. ${ }^{217}$ The order, then, spells out an appropriate number, which should suffice for purposes of proof. ${ }^{218}$ Most commonly, the plaintiff must pay the seized party for the items seized. ${ }^{219}$ The bailiff may also acquire copies containing technical and commercial information including accounting books, which may later help in assessing the extent of infringement and damages. ${ }^{220}$ The seized objects are generally stored at the courthouse and saved as proof. ${ }^{221}$ Unless expressly authorized by the order, a bailiff may not simply leave the seized items with the plaintiff. ${ }^{222}$ The statute also requires that the bailiff furnish the seized party with a copy of his written report. ${ }^{223} \mathrm{He}$ does not have to do so immediately after the inspec-

208 Véron I, supra note 157, at 138.

209 Id.

210 BIZOLLON ET AL., supra note 157, at 51.

211 Id. at $51-52$.

212 Id. at 51.

213 Id. at 38

214 Such as objects, machines, apparatuses. BIZOLLON ET AL., supra note 157, at 39.

215 BiZOLLON ET AL., supra note 157, at 39.

216 See Cass. Com., 4 janv. 1985, Dossiers Brevets 1985, IV, 5, Ann. propr. ind. 1985, 237.

217 BIZOLLON ET AL., supra note 157, at $39 \& 54$.

218 Id. at 39

219 Id. at $39 \& 54$

220 Id. at 53; Véron I, supra note 157, at 138.

221 BIZOLLON ET AL., supra note 157, at 59.

222 Id.

$223 \mathrm{Id}$. at 58 . 
tion, but, rather can finish the statement after the Saisie and send it to the plaintiff within a reasonable time. ${ }^{224}$

\section{After the Saisie: Suit and Possibility for Appeal}

Following the Saisie the plaintiff must sue and the defendant may appeal the Saisie. Art. L 615-5, I 5 CPI mandates that the rightholder file suit for the infringement which he alleged in applying for the Saisie. More precisely, the rightholder has twenty business days or thirty calendar days after the execution of the Saisie, whichever one is longer, to file the complaint. ${ }^{225}$ If the plaintiff fails to do this, the Saisie is void and the plaintiff can no longer use the evidence it produced. ${ }^{226}$ The relatively quick filing requirement preserves the Saisie's purpose as a means of gathering proof of infringement and not as a measure to intimidate competitors or promote commercial espionage. ${ }^{227}$ Although the tribunal where the infringement action is ultimately filed will often be the court having previously ordered the Saisie, this is not always the case. ${ }^{228}$

Appellate review of a Saisie occurs after its performance. ${ }^{229}$ Then, several avenues for challenging a Saisie exist. Those potential appeals either attack the legitimacy of the grant of the order or its performance. ${ }^{230}$ An appeal based on a grant's legitimacy challenges the decision of the judge having authorized the Saisie. The seized party must, thus, prove that the legal conditions required for issuing a Saisie were not met. ${ }^{231}$ If the judge is convinced, he may rescind or limit the order and thereby invalidate the evidence seized under it. ${ }^{232}$ The alleged infringer may also ask for an expedited order preventing the seizing party from proceeding with further Saisies. This, however, happens only in extreme cases, where the seizing party has gathered sufficient proof by way of conducting multiple Saisies and essentially abuses his right. ${ }^{233}$ The seized party may also appeal the performance of the Saisie and ask for its nullity. ${ }^{234}$ Those appeals are made to the court adjudicating the infringement action, rather than to the judge having issued the Saisie, based on several grounds generally relating to the seizing party having overstepped the authorizations of the Saisie order. ${ }^{235}$

225 Art. R 615-1 CPI.

226 Véron I, at 139.

227 BIZOLLON ET AL., supra note 157, at 62.

$228 \mathrm{Id}$. at 65 . The saisie-ordering and adjudicating courts are often the same, because infringement suits are litigated at the place of infringement (or harm). There, too, the evidence and, thus, the saisie tends to be. Id.

229 That is, as opposed to rules in the Intellectual Property Code. See BIZOLLON ET AL., supra note 157, at 71 .

230 Véron I, supra note 157, at 139.

231 Id.

232 Art. 496, $\{2$, NCPC (translation by the author). Art 497, NCPC expressly allows the judge to modify or retract his order even if the court in the main (infringement) suit has been seized of the matter.

233 See BIZOLLON ET AL., supra note 157, at 73 (elucidating such an "extreme" case where the seizing party had conducted several saisies and the bailiff's reports were already full of incriminating evidence).

234 Véron I, supra note 157, at 139.

235 Id. 


\section{Comparing and Contrasting the Saisie and Rule 34}

As the above explanation of Rule 34 discovery and the Saisie-contrefaçon demonstrates, the two fact-gathering mechanisms exhibit both striking similarities and differences. While the two procedures have the common objective of collecting facts probative to patent infringement, the manners in which they accomplish this diverge. What follows is an analysis of how the two procedures compare and contrast.

First, both fact-gathering mechanisms constitute codified procedural laws that have proven vital, in fact, indispensable to both domestic and cross-national patent infringement litigants. Second, both procedures as described herein are used as such only in civil cases, although both Rule 34 discovery and the Saisie have criminal counterparts in the respective legal systems. ${ }^{236}$ Third, both procedures permit judicial intervention in pre-trial fact-gathering. ${ }^{237}$ The extent and timing of such involvement differ; while the judiciary performs the Saisie $a b$ initio, the adversaries themselves propel Rule 34 inspections and courts only intervene as a last resort. ${ }^{238}$ Thus, U.S. judges" "tools" of protective orders, motions to compel, and sanctions may never come into play if the parties collaborate satisfactorily. ${ }^{239}$

Fourth, both Rule 34-discovery and the Saisie present only one of several ways in which patent infringement litigants collect proof. For example, in-court witness testimony commonly supplements the evidence generated via these procedures. Nevertheless, the Saisie is independently codified, while Rule 34 is codified as part of a series of discovery rules that help supplement it and, concurrently, define its boundaries. Fifth, because infringement evidence tends to be of a technical nature, patent cases often necessitate technically trained experts to identify relevant facts. Both Rule 34 and the Saisie respond to this need by including experts, such as scientists and engineers, in the evidence-gathering process, in appropriate cases. ${ }^{240}$ Sixth, and most importantly, both Rule 34 and the Saisie exclusively authorize the inspection of the same physical subject matter; documents, tangible things, and inspection of premises. ${ }^{241}$ Especially in patent infringement cases, relevant evidence seems to take the form of documents and items, because they often embody the infringing object or at least its traces. ${ }^{242}$

Rule 34 discovery and the Saisie diverge most prominently in the way they extract evidence, these differences seem more subtle than the similarities listed above. First,

236 However, under United States substantive law a claim for patent infringement may only be brought as a civil suit. France on the other hands allows criminal actions for patent infringement. See BIZOLLON ET AL., supra note 157, at $84-86$. In those cases a police official, rather than a bailiff, executes the search order. See Art. L. 332-1.

237 See supra Part II and Part III.

238 See supra Part II, B, 2, 3.

239 See supra Part II, B, 2, 3.

240 See supra Part II, A, 2 and Part III, B.

241 See supra Part II, A, 1, 2, and Part III, B.

242 See supra Part I. 
as mentioned previously, Rule 34 discovery is broad and the Saisie is narrow in manifold ways. ${ }^{243}$ Most importantly perhaps, discovery's broadness encompasses even inadmissible information and information which is not itself directly relevant as long as it may lead to probative evidence. ${ }^{244}$ On the other hand, the Saisie is comparatively narrow by authorizing only the inspection and sampling of evidence that may itself be probative to proving infringement.

Second, the basic concept of discovery bases on cooperation and preparation, ${ }^{245}$ while the Saisie builds on the notion of compulsion and surprise. ${ }^{246}$ This difference has several ramifications regarding the parties' actions, reactions and the entire procedure's performance. For example, the cooperation concept requires that the defendant receive notice and, consequently, an opportunity to respond in opposition to production requests. This is because discovery, generally, happens only after filing suit. ${ }^{247}$ Service of process eliminates the defendant or seized party's surprise, but, in order to prevent the destruction of probative evidence, discovery imposes an affirmative obligation upon the parties to preserve evidence. ${ }^{248}$ Although discovery anticipates that the parties collaborate absent judicial intervention, safeguards, compulsion and court interception are possible by way of orders for protection, orders compelling discovery and sanctions. ${ }^{249}$ Unlike in the Saisie, these are not the default, but only come into play after conflicts arise and the parties do not produce evidence and collaborate voluntarily as foreseen by Rule 26 .

The Saisie, on the other hand, constitutes a pre-summons mechanism. It requires less cooperation from the parties and instead operates under a concept of compulsion and surprise. As pointed out above, the seized party has little obligation to assist the bailiff in finding evidence as long as it does not directly block or deter the inspection. ${ }^{250}$ The element of surprise is essential, principally because the Saisie lacks an obligation to actively assist the adversary in finding evidence. ${ }^{251}$ Surprising the seized party with an inspection mandates ex parte proceedings by the plaintiff in applying to the tribunal for a Saisie order. This means the procedure must occur pre-summons and not provide the seized party with the option of being heard or notified and thereby enable him to destroy or hide probative evidence. Because a seized party in a Saisie is always surprised and never notified in advance, it has no opportunity to destroy probative evidence. ${ }^{252}$ Thus, the Saisie does not impose an obligation to preserve documents. The absence of a preservation requirement also relates back to the non-collaborative nature of the Saisie.

Third, Rule 34's reach to anything within the opponent's "possession, custody, and control" is broader than the Saisie. Although French law does not elaborate on this,

243 See supra Parts I \& II.

244 See FeD. R. CIV. P. 26(b)(1).

245 See supra Parts II, D.

246 See supra Parts III, A - B.

247 Except in the rare cases where courts permit Rule 27 discovery, because otherwise evidence would run risk of disappearing. See FED. R. CIV. P. 27.

248 See id.

249 See e.g. Fed. R. CIV. P. 26(c)(1); see FeD. R. CIV. P. 37(a).

250 See supra Part III, B.

251 See supra Part III, B.

252 See supra Part III, A. 
the Saisie only applies to information and items that are physically located on the premises searched and also listed in the order. ${ }^{253}$ Those items are simply located on the authorized premises; whether the seized party legally possesses, has custody or controls those items is irrelevant to the Saisie. Thus, whether discovery or the Saisie is broader depends on the specifics of a given case and the location and control of relevant evidence.

Fourth, while discovery is sensitive to privileges, the Saisie does not make an inquiry about the nature of a communication incorporated in a document. ${ }^{254}$ Again, as under point three above, anything physically located on the authorized premises, described in the Saisie order, and relevant to proving infringement of the alleged patent, is fair game. $^{255}$

Fifth, a protective order may render otherwise discoverable information under Rule 34 nondiscoverable. ${ }^{256}$ That, naturally, requires a judge to order such a safeguard, which, again, is not the default, but rather an exception that the party seeking such protection must actively prove. ${ }^{257}$ The Saisie, on the other hand, does not foresee protective orders. Its safeguards for protecting sensitive information, although not the same kind of sensitive information as recognized under United States' privilege law, apply before and after the Saisie; with discovery such protections are provided during the process. Thus, the Saisie protects sensitive information through the judge's ability to limit a Saisie order to what is relevant.

253 See supra Part III, A, B.

254 See supra Part II, B, 1.

255 See supra Part III, A - B.

256 See supra Part II, B, 2.

257 Id. 


\section{Specific Patent-Related Aspects of Evidence Gathering}

Issues such as third party discovery, trade secrets, costs, duration and extraterritorial implications are of particular interest and concern to litigants gathering patent infringement evidence. ${ }^{258}$ Both the Federal Rules and the Saisie had to tackle those issues. Their respective approaches and results are compared and contrasted below.

\section{A. Third Party Production}

Nothing in the French Intellectual Property Act's (Code de la propriété intellectuelle or CPI) relevant provisions expressly addresses third parties. However, since Saisies, generally, are permitted of persons potentially possessing evidence relating to infringement, this logically seems to include third parties. Courts agree and have permitted inspections, even if the rightholder does not anticipate suing that entity. ${ }^{259}$ Accordingly, not every person subject to a Saisie will later become a defendant. ${ }^{260}$ Conversely, not every defendant has to undergo a Saisie. ${ }^{261}$ This is especially true if the seized party only stores evidence and is essentially used as the infringer's innocent instrument. $^{262}$

Similarly, under Rule 34(c), parties may force nonparties to produce documents and items or to submit to premise inspections. ${ }^{263}$ Rule 34 simply cross-references Rule 45, which governs discovery of non-parties. ${ }^{264}$ If the court has jurisdiction under Federal Rule 45, the parties' counsel can subpoena nonparties to attend and testify or produce or permit inspections including copying of documents and tangible items in their possession, custody or control. ${ }^{265}$ Thus, the two rules are deemed corresponding and coextensive in scope. ${ }^{266}$ This means a litigant may obtain the same kind of discovery from a nonparty as from a party. ${ }^{267}$ While some courts have considered nonparty status in evaluating the burden of complying with a Rule 45 subpoena, at least one notable commentator recommends that courts should, instead, apply an equal scope of duty and alleviate the nonparty's burden by, for example, obliging the requesting party to reimburse the cost of production. ${ }^{268}$

258 See generally Kenneth R. Adamo et al., Document Discovery in Patent Litigation, in PATENT LiTIGATION STRATEGIES HANDBOOK 2004 CUMULATIVE SUPPLEMENT supra note 1.

259 See BIZOLLON ET AL., supra note 157, at 65.

260 See id.

261 Id. at 65.

$262 I d$.

263 FED. R. CIV. P. 34(c).

264 See id.; FED. R. CIV. P. 45.

$265 \mathrm{Id}$. at 45(a)(3) (authorizing attorneys, as officers of the courts before which they are licensed to practice, to issue and sign subpoenas on the courts' behalf).

2667 MOORE ET AL., supra note 89, at \$34.02[5][a] (asserting that the languages and interpretations of the two rules have evolved so as to parallel each other, as shown, for example by the fact that now attorneys may subpoena non-parties without judicial assistance).

267 Id. at $\$ 34.02[5][\mathrm{d}]$.

268 See id. 
Patent infringement litigants commonly utilize third party discovery for computing lost profits and royalties. ${ }^{269}$ For example, when third parties offer reasonable substitutes or competitive technologies to the patent-in-suit, evidence relating to such activities may assist in approximating the patent owner's market share or industry royalty rate. ${ }^{270}$

Because the practical reality, in both the United States and France, is that relevant evidence is not concentrated but rather dispersed across several entities some of which may not be litigants, both the Rule 34 and the Saisie permit third party inspection of documents, things, and premises. Both procedures allow inspections of third parties in the same manner and to the same extent as inspection of primary parties. The ability to reach third parties is justified in light of the fact that patents frequently undergo transactions such as licensing and sale. Further, the ability to compel third party production discourages infringers from storing and effectively hiding infringement evidence with nonparties. Regarding third party production, the two procedures are equally far-reaching and similarly facilitate patent enforcement.

\section{B. Trade Secrets and Secret Commercial Information}

Striking a fair balance between the seized party's interest in adequately protecting trade secrets and confidential information, on one hand, and ensuring the seizing party an effective and efficient procedure, on the other, has presented controversies in French Saisie practice. ${ }^{271}$ Modern Saisie practice shields defendants' commercial secrets to some extent by barring the plaintiff or other non-neutral parties from participating in the Saisie and, thereby, entering the seized parties premises and observing secret operations thereon. ${ }^{272}$ After the procedure, a seized party's objection to a description and confiscation, too, may be honored by having an appointed expert sort through the information and thereby keeping some, albeit non-relevant information, from the adversary's view. ${ }^{273}$

Inveiglement of trade and commercial secrets constitutes a ground for appealing the performance of a Saisie. ${ }^{274}$ Despite the apparently legitimate threat of having one's trade secrets divulged during a Saisie, courts rarely look favorably on such complaints. ${ }^{275}$ In fact, the seized party cannot recover damages awards for improper revelation of trade secrets, unless the seized party demonstrates harm. ${ }^{276}$ Moreover, it bears the burden of proving that the seizing party directly profited from having

269 MoORE, Michel \& LuPO, supra note 124, at 134.

$270 \mathrm{Id}$. at 144.

271 See BizOLlon ET AL., supra note 157, at 56 - 58 ("The difficulty lies in reconciling the rights of the seizing party in obtaining proof of infringement and respecting the secrets of the seized party") (translation by the author). Id. at 56 .

272 TGI Paris, $3^{\mathrm{e}}$ ch., $3^{\mathrm{e}}$ sect., 15 oct. 2002, PIBD 2003, $\mathrm{n}^{\circ} 763$, III, 238 (canceling an order authorizing a saisie for the sole reason that the seizing party himself joined and assisted in the saisie).

273 Véron I, supra note 157, at 138.

274 BizOLLON ET AL., supra note 157, at $78-79$.

275 See Pierre Véron, study, "Le contentiex des brevets d'invention, etude statistique 1990-1999," available at $\mathrm{http}: / /$ www.veron.com/iplibrary.php?langs=fr\&Session_site=f2f5ffa20b8e4cab0cb0ebac20b26add.

276 BIZOLLON ET AL., supra note 157, at 78. 
accessed such information and that this knowledge is entirely distinct from the alleged infringement. $^{277}$

Federal Rule 26(c) similarly permits, but does not guarantee, trade secret protection. While it specifically addresses the protection of "trade secret[s] or other confidential research, development or commercial information" 278 as part of its non-exhaustive list for which protective orders may issue, no absolute guarantee exists that a court will actually protect such information. ${ }^{279}$ Often the parties simply agree on how to limit access to sensitive materials absent court involvement. ${ }^{280}$ Courts have discretion over whether and in what form to issue protective orders under Rule 26(c)(1). ${ }^{281}$ In patent infringement cases, applications for protective orders under subsection $(\mathrm{c})(1)(\mathrm{g})$ are especially common, because trade secrets and confidential know-how tend to accompany efficient use of patents.

Under the Federal Rules, courts have developed a three-pronged analysis for determining whether to issue a protective order. Accordingly, the applicant must prove (1) that the subject matter actually qualifies as a trade secret or similar confidential information, (2) discovery of the information would cause "cognizable harm," and (3) "good cause" by demonstrating "clearly defined and serious injury."282 The third prong essentially weighs the potential competitive injury, which is deemed graver in case of competitors, ${ }^{283}$ against the need for disclosure. ${ }^{284}$

In practice, patents often coexist and depend on trade secrets. That reality, too, transcends national borders. Thus, both the Federal Rules and the Saisie respond to the threat of divulging such secrets during evidence gathering. Because the extent and scope of trade secrets' entanglement with relevant patent information depends on the specifics of any given case, both procedures leave the assessment of whether to protect such information to the courts' case-by-case discretion. Interestingly, neither procedure permits a blanket and express exception for trade secrets, but rather gives the court discretion to balance the interests implicated by divulgation vis-à-vis protection.

The compulsory nature of the Saisie, as compared to cooperation-driven discovery, typically leaves U.S. litigants deciding extrajudicially what subject matter merits

277 Id.; see CA Paris, $4^{\mathrm{e}}$ ch., 17 mai 1995, PIBD 1993, nº592, III, 343.

278 FED. R. CIV. P. 26(c)(1)(G).

279 See FED. R. CIV. P. 26(c); Centurion Indus., Inc. v. Warren Steurer \& Assoc., 655 F.2d 288, 325 (10th Cir. 1981). "There is no privilege against the discovery of confidential business information." Bruner, 30 FEDERATION INS. COUN. Q. 205, 247 (1989); see also JUNKER, supra note 12, at 129 - 130 (stating that with this phrase United States law shocks foreign businesses). German law, for example, provides more although in practice not significantly more protection for trade secrets. Id.

2807 MOORE ET AL., supra note 89, at \$34.12[4].

281 See Lupo, supra note 132 at 133 (suggesting that courts, generally, ensure protection of such information in appropriate cases). E.g. Petz v. Ethan Allen, Inc., 113 F.R.D. 494, 497 (D. Conn. 1985) (limiting inspection to Plaintiff's attorney).

282 Zenith Radio Corp. v. Matsushita Elec. Indus. Co., 529 F. Supp. 866, 889 - 90 (E.D. Pa. 1981); MOORE, MiCHEL \& LUPO, supra note 124, at 165.

283 See Coca-Cola Bottling Co. v. Coca-Cola Co., 107 F.R.D. 288, 292 (D. Del. 1985) (allowing disclosure because parties were not competitors).

284 See id. at 290 ("disclosure of trade secrets in litigation ...could become ...the means of ruining an honest and profitable enterprise" quoting 8 J. WIGMORE, EVIDENCE $§ 2212$ at 155 (McNaughton rev. 1961); see e.g. American Standard Inc. v. Pfizer, 828 F.2d 734, 738 - 41 (Fed. Cir. 1987) (disclosure of research and development materials to competitor would result in commercial disadvantage and irreparable harm). 
trade secret protection, while the judge or bailiff makes this determination under the French process. Even if the controversy reaches the courts, trade secrets in U.S. litigation have a better chance of being protected ex ante. There, the judge balances the interest in disclosing the trade secret in order to avail the plaintiff of infringementrelated evidence against guarding the trade secret and thereby potentially denying access to infringement proof. Only after this balancing analysis does the court permit or deny trade secret divulgation.

French courts, on the other hand, always permit divulgation of trade secrets if this also reveals patent infringement proof. French courts merely make an ex ante inquiry. That is, they consider a trade secret proprietor's loss in having his secrets divulged after divulgation already occurred and, then, may award damages if the seized party establishes that the disclosure actually caused him a financial loss.

Under the Federal Rules, discovery's pre-production consideration of trade secrets better accommodates the vital need to preserve the secrecy of certain information not sufficiently connected to the infringement to merit production. Discovery's sensitivity to trade secrets also deters abuse by ensuring that pre-trial fact-gathering does not become an excursion to spy on competitors. In addition, preliminary evaluations of what trade secrets deserve protection eliminate the need for more costly post-disclosure judicial review and damage assessment.

\section{Costs}

While the complexity of a case ultimately controls its price tag, the Saisie constitutes a relatively inexpensive procedure. ${ }^{285}$ The bailiff fees are low because he is employed by the state. ${ }^{286}$ Also attorney, patent agent and expert fees are low, because the procedure takes only hours or days. ${ }^{287}$ In France, the losing party generally pays the cost of litigation, including attorney's fees. ${ }^{288}$ However, the lump sums awarded by the courts usually do not actually cover the expenses incurred. ${ }^{289}$

Generally, under the Federal Rules, each party must bear its own financial cost of complying with discovery. ${ }^{290}$ However, courts have the discretion to shift such expenses to the requesting party if the cost allocation would unduly burden the producing party. ${ }^{291}$ Increased demand for extensive electronic discovery has skyrocketed discovery expenses. ${ }^{292}$ This phenomenon has prompted courts to balance interests and permit cost-shifting in appropriate cases. ${ }^{293}$

285 Paule Drouault-Gardrat, Enforcing Patent in France, ๆ 14, website, Bird \& Bird Articles Archive (Aug. 22, 2005), http://www.solutionslab.com/english/publications/books/index.cfm.

286 Philippe Mueller, supra note 150, at 32.

287 Véron I, supra note 157, at 139.

288 Paule Drouault-Gardrat, supra note 285, at 914

289 Id

290 Indeed, pursuant to the "American Rule" each party foots its own litigation bill.

291 See FED. R. CIV. P. 26(b)(5). Economic theory also supports costs-shifting, because it deters excessive discovery and other abusive discovery practices, such as threatening discovery for its nuisance value, by obliging the requesting party to internalize the cost of discovery. ROBERT G. BONE, CIVIL PROCEDURE: THE ECONOMICS OF CIVIL PROCEDURE 229 - 30 (Foundation Press 2003).

292 See e.g. 7 MOORE ET AL., supra note 89, at \$34.12[3][b], [e].

293 E.g. OpenTV v. Liberate Techs., 219 F.R.D. 474, 477 (N.D. Cal. 2003); Zubulake v. USB Warburg LLC, 216 F.R.D. 280, 284 (S.D.N.Y. 2003). 
Concerning costs, the procedures differ radically. The Saisie is notably cheap, while discovery is notoriously expensive. Further, while any direct involvement in U.S. litigation usually comes at a high price for all parties, only the losing party in French litigation pays significantly. Of course, in any loser-pay-all system, the incentive to file suit is reduced.

\section{Duration}

Typically, a Saisie is performed only once and takes no more than a day. ${ }^{294}$ Accordingly, the order authorizes the bailiff and his team to enter and inspect the defendant's premises on a single occasion specified in the order. ${ }^{295}$ Nevertheless, when a bailiff left due to opposition and disrespect from a defendant and returned three days later to continue the Saisie, the court deemed this as a mere extension of the previous Saisie rather than as a new procedure mandating a separate order. ${ }^{296}$ Although courts may order multiple Saisies if the plaintiff needs these to gather proof, they are reluctant to order several, because then the Saisie tends to lose its evidence-procuring objective and, instead, punishes or exposes the defendant. ${ }^{297}$ This constitutes an abuse of Saisie entitling the defendant to damages. ${ }^{298}$

Theoretically, therefore, the entire evidence-gathering procedure - from filing the Saisie request, to conducting the search, to filing suit - can be finished within a few days. Due to the short time frame between performing the Saisie and having to file suit, the parties have little room to delay the proceedings. ${ }^{299}$

Discovery under the Federal Rules, on the other hand, takes several months or even years. ${ }^{300}$ In contrast to the Saisie, where narrowness and judicial oversight leave litigants little opportunity to postpone litigation, discovery litigants are much more able to speed up or slow down the evidence-gathering process. The parties' ability to direct the timing and initiation of Rule 34 discovery is subject to the interplay of Rules 16 and $26 .{ }^{301}$ Thereafter, the parties largely control the timing of documentary and inspection requests as well as other forms of discovery. ${ }^{302}$ United States judges expect proactiveness and cooperation from litigants. ${ }^{303}$ Parties should actively and jointly pursue discovery without requesting judicial assistance. ${ }^{304}$ Consequently, courts have

294 Yves Marcellin, La Saisie-Contrefacon, 178 - 179 (3d ed. Cedat 2001); Véron I, supra note 157 , at 139 .

295 MARCELLIN, supra note 294, at 179.

296 Paris, $4^{\dot{e}}$ ch., sect. B, 14 mars 1991, RD propr. ind., $\mathrm{n}^{\circ} 35-36,1991$.

297 See MARCELLIN, supra note 294, at 213 - 214.

298 Id.

299 Art. R 615-1 CPI (allowing circa one month).

300 E.g. Véron I, supra note 157, at 139.

301 See FED. R. CIV. P. 26 \& 16.

302 Valerie Davies \& Thomas N. Pieper, English Disclosure and U.S. Discovery, in Transatlantic COMMERCIAL Litigation AND ARBITRATION, supra note 13, at 233, 236. However, the court has wide discretion under Rule 16 to manage and schedule discovery and to restrict the frequency and $303 I d$ extent of discovery due to burdensomeness, convenience and cost under Rule 26.

304 Id. 
little sympathy for parties who chose to "sit on their hands." 305 Depending on the issues' complexity, courts, generally, permit between three and twenty-four months for discovery. ${ }^{306}$

Accordingly, in terms of timing, the Saisie better accommodates patent litigants, as well as the industries and consumers making use of patented inventions. This is because quick resolutions of infringement issues restores certainty in the market and thereby increases transactions (such as licensing) involving the patent as well as further improvements of the invention it incorporates. This procedural aspect also makes litigation and the enforcement of patents less burdensome to the rightholder and thereby strengthens his right to the full extent permitted by the substantive law.

\section{E. Extraterritorial Application}

Besides Belgium, no other country knows the Saisie as it exists in France. ${ }^{307}$ While the Saisie is unique to those two jurisdictions, the United States and Japan remain the only countries litigating significant numbers of patent cases that entirely lack a comparable measure for securing evidence. ${ }^{308}$ This absence of such a pre-summons, ex parte measure means that infringers can systematically destroy proof of infringement as long as no lawsuit exists, and rightholders may not legally access premises hosting infringing operations to secure such evidence before filing suit.

The laws of Italy and Spain, which generally share significant commonalities with the French legal system, know measures similar to the Saisie. ${ }^{309}$ Even the United Kingdom, as well as many of its former colonies following a substantially-similar common law system, ${ }^{310}$ permit ex parte civil searches for purposes of securing infringement evidence before service of process. ${ }^{311}$ The orders permitting such searches, known as Anton Piller orders, direct the respondent, who as in the Saisie is often the defendant later, to permit certain people to enter his premises for inspecting, copying, searching and potentially removing certain enumerated items. ${ }^{312}$ However, the British practice differs from the Saisie in that it requires more proof by the rightholder before granting

305 Id.

306 Id. Such a timeframe would be noted in the scheduling order. See FED. R. CIV. P. 16 (b)(1).

307 BIZOLLON ET AL., supra note 157, at 3.

308 Interview with Judge Takami Shintaro, Associate Justice, Osaka District Court, Japan, in Munich, Germany (Aug. 26,2008). All European Member States had to adopt such measures under Article 7 of Directive 2004/48/EC of the European Parliament and of the Council of 29 April 2004 on the enforcement of intellectual property rights. Council Directive 2004/48/EC, 2004 O.J. (L 157) 32 (EC) (Enforcement Directive).

309 Bertoni et al., Forum Shopping Prospers Despite Enforcement Directive, 69 - 70, Managing IP (July/ August 2008).

310 See Daniel S. Drapeau, Anton Piller Orders: The Latest Word from the Supreme Court, the Federal Court of Appeal and the Federal Court, 20 InTELL. PROP. J. 39 (2006) (explaining the history of Anton Piller Orders in the U.K. and their adoption by the Canadian judiciary).

311 British Civil Procedure Rules (CPR) 1997, §7. Before being codified, this practice was authorized by case law under Anton Piller KG v. Manufacturing Processes, [1976] Ch 55 and its progeny.

312 CPR 1997, §7; Bertoni, supra note 309, at 70. 
an inspection. ${ }^{313}$ As mandated by the Directive 2004/48/EC, ${ }^{314}$ Germany, which previously lacked a procedure analogous to the Saisie, finally, adopted a preliminary measure permitting rightholders to secure evidence of infringement. Because this law was only recently implemented, it remains unclear how effective and powerful a tool it provides to rightholders. ${ }^{315}$

Despite the availability of similar measures in other jurisdictions, none reward such a relatively modest effort by the plaintiff with a right as potent as the Saisie. ${ }^{316}$ This, coupled with many jurisdictions' welcoming reception of evidence gathered under the Saisie, ${ }^{317}$ has made it a popular instrument for plaintiffs all across Europe. ${ }^{318}$ The Saisie lends itself markedly well for export. It touts a track record of frequent involvements in cross-border disputes and often generates evidence that ends up in litigations outside France. ${ }^{319}$ In fact, many European law firms use the opportunity of applying the Saisie extraterritorially as an advertising tool. Scores of websites boast how their attorneys can attain quality infringement evidence cheaply and effectively via a Saisie. ${ }^{320}$ This is usually done by way of filing a pro forma lawsuit in France that avails plaintiffs of the Saisie procedure, while, concurrently, filing an infringement suit elsewhere ${ }^{321}$ and actually pursuing the main infringement action there with the help of the Saisie-adduced proof. ${ }^{322}$ This requires plaintiffs to own the same patent

313 That is, the rightholder must demonstrate that the infringer will likely destroy evidence. See Bertoni, supra note 309 , at 70 .

314 Enforcement Directive, supra note 308. The German Bundesrat, at last, transposed the Enforcement Directive on May 23, 2008.

315 In fact, the German lawmaker exceeded the deadline for implementing the Enforcement Directive, on April 29, 2006, by over two years.

316 BizOLlON ET AL., supra note 157, at 3; see generally Larry Coury, Note, C'est What? Saisie! A Comparison of Patent Infringement Remedies among G7 Economic Nations, 13 FORDHAM INTELL. PROP. MEDIA \& ENT. L.J., 1101, 1152 - 1154, 1158 (2003).

317 Cohen \& Kohler, supra note 159 (characterizing Germany as a jurisdiction "reticent with respect to disclosure injunctions but at the same time open to the use of disclosure results obtained in foreign jurisdictions.")

318 See Bertoni, supra note 309, at 69.

319 Id.

320 E.g. Jochen Bühling, Obtaining Evidence When Preparing Patent Litigation, ๆ 14 \& 32, IP VALUE 2008, available at http://www.buildingipvalue.com/06EU/172_175.htm. (Explaining the saisie-contrefacon and previously stating: [W]hen advising clients about the necessary evidence, the possibility of obtaining evidence in other countries should always be considered."); e.g. Allen \& Overy, website, available at http://www.allenovery.com/AOWEB/Knowledge/Editorial.aspx?contentTypeI $\mathrm{D}=1$ \& contentSubTypeID=7945\&itemID=27083\&prefLangID=411. ("We set up offensive strategies[,] such as filing simultaneous actions for patent infringement and gathering evidence of infringement in various countries by conducting saisie-contrefaçon in France[,] as well as defensive strategies $[\ldots] . . ”)$

321 Generally, plaintiffs seek fora proffering sizable damage awards (meaning the extent of the harm and, thus, the market - must be large) as well as speedy adjudications and IP-specialized judges. Germany's district courts in Duesseldorf and Munich have, particularly, good reputations and plaintiffs often chose these tribunals to litigate important infringement claims. E.g. Richard A. Egli, The Main Patent Litigation Countries in Europe, 366 PRAC. L. INST./PAT. 35, 56- 57 (1993) (ranking the major European patent litigation jurisdictions based on cost, procedural complexity, control, manageability and predictability of outcome, and sophistication; Switzerland wins, beating Germany by one point.); World Intellectual Property Organization, Advisory Committee on Enforcement, Second Session, Intellectual Property Litigation Under the Civil Law Legal System; Experience in Germany, WIPO/ACE/2/3, 3 - 8 (June 4, 2004) (prepared by Joachim Bornkamm). Professor Bornkamm is a judge at the German Supreme Court.

322 See ALLEN \& OVERY supra note 320. 
right in both France and the adjudicating jurisdiction, which, nowadays, often holds true, especially as regards European patents.

While the Saisie constitutes an admired and respected procedural tool for export, extraterritorial discovery under the Federal Rules has not been similarly welcomed and, indeed, has spawned what some term a "judicial conflict." 323 This is especially true for European civil law countries, which perceive the practice of discovery on their soil as offensive to their judicial sovereignty. ${ }^{324}$ There, courts are charged with conducting depositions and gathering evidence. ${ }^{325}$ Thus, the practice of attorneys performing depositions, making inspections, and requesting documents and items outside the presence of a judicial officer insults the judiciary's very raison d'etre. ${ }^{326}$ The civil law countries' discontent with discovery within their borders ultimately led to the conclusion of The Hague Convention on the Taking of Evidence Abroad in Civil or Commercial Matters (Hague Convention), ${ }^{327}$ which establishes rules for gathering evidence abroad. $^{328}$

The Hague Convention allows letters of requests through foreign courts, notices to appear before consular officers, and designation of private commissioners. ${ }^{329}$ These procedures restrict U.S. lawyers from running wild in attempting to depose foreign litigants abroad or directly request information from them. However, the United States Supreme Court limited the effect and significance of the Hague Convention in Societe Nationale Industrielle Aerospatiale v. United States Dist. Ct., by holding that application of the convention is merely optional and, moreover, that the party seeking to pur-

323 See e.g. Samuel Baumgartner, Is Transnational Litigation Different? 25 U. Pa. J. Int'1 Econ. L 1297, 1313,1326 - 1353 (2004) Judicial conflict or "Justizkonflikt" as first termed by German legal commentators essentially means a clash in two jurisdictions' procedures, which ultimately hampers and blocks the litigants' access to efficient and effective cross-border adjudication. See id at 1313-1314; see also ROLF STÜRMER ET AL., DER JUSTIZKONFLIKT MIT DEN VEREINIGTEN STAATEN VON AMERIKA (Walther J. Habscheid ed., Gieseking 1986) (including essays on the judicial conflict between the United States and Europe).

324 RESTATEMENT (THIRD) OF ForEIGN RELATIONS LAW § 442, Reporter's Note 1 (1987) ("No aspect of the extension of the American legal system beyond the territorial frontier of the United States has given rise to so much friction as the request of documents in investigation and litigation in the United States.")

325 Baumgartner, supra note 323, at 1351. Additionally, discovery's enablement of fishing expeditions and abuses such as overproductions (paper avalanches) has invited criticism from civil law scholars. See e.g. JUNKER, supra note 12 at $172-173$.

326 See Baumgartner, supra note 323, at 1313 - 1322 (explaining that German lawyers perceived U.S. litigation as "both crude and threatening" because of "expensive party-driven discovery with comparatively immense scope and scant protection of trade and business secrets; and a willingness of at least some U.S. courts to enforce their procedural rules transnationally in the face of sovereignty objections by the foreign governments involved.") Id. at $1320-1321$.

327 Federal Rule 28(b) references to the Hague Convention for taking depositions abroad.

328 Hague Convention on the Taking of Evidence Abroad in Civil or Commercial Matters, opened for signature Mar. 18, 1970, 23 U.S.T. 2555; see 6 MOORE ET AL., supra note 13, at \$28.11[1]. All of the major patent litigations jurisdictions, except Japan,are signatories to the Hague Convention See Art. 42 (listing countries such as France, Germany, Italy, Netherlands, Spain, U.K. and the United States.)

329 Discovery under the Hague Convention is independent and alternative from Federal Rules discovery. See 6 MOORE ET AL., supra note 13, at $\$ 28.12-14$. In choosing between Federal Rules or the Hague Convention, discovery, post-Aerospatiale courts consider the specific facts of a case such as: (1) the sovereignty interests involved, (2) the nature and intrusiveness of the discovery requested, (3) the probability that Hague Convention will effectively produce evidence. See e.g. In re Pierre Bottled Water Litig., 138 F.R.D. 348, 354 (D.Conn. 1991). 
sue discovery under the convention must show that it should apply. ${ }^{330}$ Thus, United States litigants may disregard the Hague Convention entirely and resort directly to the Federal Rules of Civil Procedure in conducting discovery abroad. ${ }^{331}$ That comes back, full circle, to the risk of offending foreign nations' judicial sovereignty - a concern that did not seem to bother the Aerospatiale Court. ${ }^{332}$ However, the legal and political backlash created by discovery perceived as offensive may ultimately disserve United States litigants in foreign courts ${ }^{333}$ and can motivate reactive legislation such as blocking statutes. ${ }^{334}$

Under the Federal Rules, discoverable materials need not be located within the court's territorial jurisdiction; personal jurisdiction of the controlling entity suffices to enforce a Rule 34 request. $^{335}$ The Saisie's extraterritorial reach differs in that a French tribunal cannot reach beyond its geographic jurisdiction. Thus, the commonly-introduced Saisie-evidence in non-French tribunals was actually gathered in France and simply transported abroad for purposes of litigating the merits of a patent infringement action. The Federal Rules and Aerospatiale, however, do not similarly restrict a United States court from ordering the production of documents and things beyond that court's geographic district or even confine it to the United States. ${ }^{336}$ Thus, discovery is much more aggressive than the Saisie, in that it applies itself in a foreign country, and, what is more, without necessarily requesting that country's approval. ${ }^{337}$

330 Societe Nationale Industrielle Aerospatiale v. United States Dist. Ct., 482 U.S. 522, 533, 539 - 541 (1987).

331 Id.; Brief of the Government of the Federal Republic of Germany as Amicus Curiae in Support of Respondent, Societe Nationale Industrielle Aerospatiale v. United States Dist. Ct., 482 U.S. 522 (1986) (No. 85-1695); see generally. Baumgartner, supra note 323, at 1331 - 1348 (adding that the drafters of the Federal Rules helped create the judicial conflict by failing to consider the different manner in which civil law jurisdictions collect evidence) $I d$. at 1348. German law, on the other hand, perceives a U.S. court's order of taking discovery under the Federal Rules in a foreign state absent that state's consent as a violation of public international law. JUNKER, supra note 12, at $368-369$. The DOJ used to support the same view. See Brief for the United States as Amicus Curiae, at 10, 12, In re Anschuetz \& Co., GmbH, 754 F.2d 602 (5th Cir. 1985), vacated sub nom. Anschuetz \& Co., GmbH v. Mississippi River Bridge Authority, 107 S. Ct. 3223 (1987) (No. 85-98).

332 Brief of the Government of the Federal Republic of Germany as Amicus Curiae in Support of Respondent, Societe Nationale Industrielle Aerospatiale v. United States Dist. Ct., 482 U.S. 522 (1986) (No. 85-1695).

333 Baumgartner, supra note 323, at 1347 - 48. (suggesting that the United States' ignorance in conducting discovery abroad has contributed to laws and attitudes in Germany which have disadvantaged U.S. parties' access to evidence located in Germany)

334 McKay, 16 N.Y.U.J.. Int'1 L. \& Pol. 1217, 1223 - 1226 (listing all blocking statutes existing at that time). "A blocking statute is a law passed by a foreign government imposing a penalty on a national for complying with a foreign [United States] court's discovery request." 6 MOORE ET AL., supra note 13 , at $\$ 28.16$. Such blocking statutes do not prevent a U.S. court from ordering discovery from a party over which it has jurisdiction, even if discovery compliance would violate the statute. $I d$. A party claiming that a foreign blocking statute prevents its production of certain materials, must make a good faith effort to have the foreign government waive the statute. The extent of effort which the nonproducing party exerts in seeking waiver controls the sanctions it will receive for noncompliance. Id. Since World War II every important trading partner of the U.S. has passed a blocking statute, which in practice serves to protect domestic undertakings from U.S. discovery requests "Vorlageanordnungen." JUNKER, supra note 12, at 395 - 397. Almost all countries having enacted blocking statutes did so in response to unilateral U.S. extraterritorial discovery efforts which the blocking nations perceived as threatening to a particular industry. BORN \& WESTIN, supra note 19, at 282-283.

3357 MOORE ET AL., supra note 89, at \$34.14[2][b].

336 BORN \& WESTIN, supra note 19, at 266 (suggesting that documents or things discoverable by Rule 34 must not be within the territorial jurisdiction of the court).

337 See id. at 264-267; see generally Baumgartner, supra note 323, at $1320-21$. 
Accordingly, comparing the Saisie and discovery's respective popularities when exported may be unjust, because the extent to which they apply extraterritorially (that is, beyond France and the United States, respectively) differs starkly. The Saisie itself is not subject to export, but the information it generates is. With regard to discovery, on the other hand, the mechanism itself is subject to export but, unlike in the case of the Saisie, not for purposes of a foreign but for a domestic action. ${ }^{338}$ Despite these significant differences regarding extent and objective, both evidence-gathering devices are renowned for their extraterritorial application - the nature, extent, and reception of which differ significantly and help shape the picture of cross-border patent litigation.

338 See BORN \& WESTIN, supra note 19, at 266 - 267 (suggesting that U.S. courts prefer using the Federal Rules, rather, than the Hague Convention, for gathering proof for domestic actions). 


\section{Evaluative Comparison of the Procedures' Strengths}

As the above expositions of Rule 34 discovery and the Saisie demonstrate, both factgathering procedures accommodate issues particular to the patent infringement context. While in some instances the U.S. approach proves more effective, efficient, and considerate, the French mechanism prevails in other areas. The Saisie dominates regarding its ability to preserve quality evidence, deterring overproduction, and reducing costs and duration associated with enforcement of patent rights as well as its ability to translate well into the international context. Rule 34's discovery mechanism, on the other hand, is preferable for its heightened trade secrets protection and its sensibility to other communications and information transmitted within certain privileged contexts.

With regard to the Saisie's strengths, the first and most noteworthy lies in its ability to secure evidence catching infringers in the act and, thereby, foreclosing them from destroying or concealing infringement proof and evading enforcement of the patent laws. ${ }^{339}$ This preservation capacity results from the Saisie's ex parte nature and the surprise effect this creates for the alleged infringer. While the European legislator has interpreted the need for effective enforcement of intellectual property rights to embrace a right to such ex parte civil searches, ${ }^{340}$ the Agreement on Trade-Related Aspects of Intellectual Property Rights (TRIPS) ${ }^{341}$ does not per se require such ex parte measures. It more vaguely instructs World Trade Organization Members to implement effective enforcement procedures ${ }^{342}$ and compel, in appropriate cases, the production of evidence while, simultaneously, protecting trade secrets. ${ }^{343}$ Thus, while the United States does not seem to violate TRIPS' enforcement provisions by lacking a realistically available ex parte measure ${ }^{344}$ the implementation of such measures all across Europe and countries such as Canada $^{345}$ reflects a heightened international standard for patent enforcement.

Although Rule 34 discovery is broad, it does not prevent destruction or concealment of probative evidence as long as this occurs pre-suit or at least before the potential defendant has notice. ${ }^{346}$ It seems that a defendant who willingly engages in patent infringement may not hesitate to make traces of his illegal conduct disappear when he anticipates the possibility of legal action. An infringer could, then, destroy or hide evidence, just before receiving reasonable notices of the suit and, under the current spo-

339 See supra Part III, A-B.

340 Enforcement Directive, supra note 308, art. 7.

341 Art. 39, Apr. 15, 1994, 33 I.L.M. 81 (1994).

342 Id. at art. 41.1.

343 Id. at art. 43.

344 Courts so rarely grant preliminary Rule 27 requests that rightholders can not rely on this discovery device for securing evidence pre-suit.

345 See supra Part IV, E.

346 See supra Part II. 
liation standard stand a good chance of avoiding punishment for patent infringement. $^{347}$

Second, the Saisie more effectively avoids and deters overproduction - the infringer purports to comply with discovery requests, but does so by producing a file dump consisting of excessive volumes of documents and information to hide damaging documents. ${ }^{348}$ Discovery is known for having this problem. ${ }^{349}$ The Saisie avoids such abuse, because the requesting party, rather than the producing party, more closely designates the evidence to be gathered. ${ }^{350}$ Discovery-style overproduction not only makes the fact gathering more expensive, but also diminishes the procedure's effectiveness by potentially preventing relevant information from being found.

Third, the Saisie's speedy process and relative cheapness better serve the effective enforcement of patent law across a wider spectrum of rightholders than expensive and prolonged discovery. ${ }^{351}$ Enforcing a valid patent should be a realistic possibility for every rightholder. However, if large amounts of cash and the patience to litigate for years constitute prerequisites for such enforcement, then not every rightholder can afford to enforce his patent. Such a realistic inability to enforce a patent essentially robs the patent of its value, at least in the hands of that rightholder. Thus, a procedure requiring significant expenditures of time and money discriminates against small patentholders, because those typically have less money and work on shorter time schedules.

Fourth, the Saisie better serves international comity and export interests. ${ }^{352}$ This is because it is less aggressive in that it does not apply extraterritorially and fits better into both civil and common law contexts than discovery does. As noted above, the Saisie, unlike Rule 34 discovery, does not permit French courts to order Saisie-style production outside the territorial jurisdiction of the court. ${ }^{353}$ Such geographically restricted jurisdiction necessarily forecloses the Saisie from conflicting with other courts' jurisdictions outside of France. Thus, the Saisie can not be forced upon foreign sovereigns. If a non-French tribunal wishes to use the proceeds of a French Saisie it is free to do so, but the Saisie-ordering court has no power to effect such a decision.

Rule 34 discovery, on the other hand, often violates foreign sovereignty in that it applies extraterritorially in the same manner it does domestically. ${ }^{354}$ Because civil law countries have reserved evidence gathering for their judiciaries, they perceive the unilateral imposition of party-driven discovery as excessively aggressive and offensive. And justly so; after all, why allow foreign attorneys to perform activities that not even

347 See supra Part III, A, 4.

348 See e.g. Kuo-Chang Huang, Mandatory Disclosure: A Controversial Device with No Effects, 21 PACE L. REV. 203, 218 (2000) (explaining that overproduction of information constitutes an undesirable phenomenon under discovery).

349 See supra Part II; see also Lee H. Rosenthal, A Few Thoughts on Electronic Discovery after December 1, 2006, 116 YALE L.J. POCKET PART 167 (2006) (stating that overproduction increases the cost, burden, and time required to review and produce information.)

350 See supra Part III, A.

351 See supra Part III.

352 See supra Part V, E.

353 See supra Part V, E.

354 See supra Part V, E. 
locally-licensed lawyers are permitted to engage in? In light of the fact that sovereign nations are generally free to enact laws applicable within their own borders, ${ }^{355}$ discovery is too aggressive in the international realm, due to its failure to involve foreign judicial and legal systems.

The Saisie also fits better within the civil and common law contexts, while discovery only translates well into other common law jurisdictions. The Saisie, as a procedural construct of the French legal system, naturally suits civil law norms. Civil law judges are more able to comprehend the Saisie's context, because they are trained in civil law procedure. The context and concept of discovery, however, differ starkly from those familiar to civil law judges. Due to this unfamiliarity, discovery is received with skepticism by civil law judges. The Saisie, conversely, does not offend common law legal systems, because, as shown above, it does not unilaterally impose itself.

Discovery, on the other hand, imposes itself extraterritorially as it does domestically. The combination of such an aggressive extraterritorial approach, which bypasses the civil law mandate of judicial oversight, and civil law judges' ignorance of common law procedure in general makes discovery difficult to export into civil law jurisdictions. While other common law jurisdictions familiar with the general concept of discovery may prove more sympathetic, most jurisdictions in which significant numbers of patent cases are litigated have civil law regimes and, therefore, discovery tends to face skepticism in cross-border patent litigations. Accordingly, extraterritorial patent discovery is predisposed to clash, offend and be received with skepticism, while the Saisie is respected by and appeals to foreign courts adjudicating infringement actions.

Discovery under Federal Rules, however, proves preferable and more sophisticated than the Saisie in other respects. Its collaborative atmosphere and ex ante protection of trade secrets and privileged communications more aptly accommodate patent policy and establish certainty. ${ }^{356}$ Extensive judicial involvement in fact-gathering taxes the State for the resolution of legal disputes which only distantly benefits society and would better be borne by the litigants themselves. ${ }^{357}$ Thus, discovery's default of letting the parties gather evidence cooperatively seems a better-suited cost-allocation that, at least theoretically, should induce the parties to avoid excessive litigation. In the U.S. system, parties have to bear their own discovery costs, which helps encourage settlement. In the French Saisie system, where no lawsuit exists at the time of the Saisie, allocating more pre-trial costs to the parties would deter the filing of undersubstantiated lawsuits. ${ }^{358}$

Unlike the Saisie, discovery properly accommodates trade secrets. ${ }^{359}$ Article 39 of TRIPS requires protection of trade secrets. ${ }^{360}$ Because trade secrets typically accom-

355 See e.g. R.M.S. Titanic, Inc. v. Haver, 171 F.3d 943, 964 (4th Cir. 1999); U.S. v. \$734,578.82 in U.S. Currency, 286 F.3d 641, 660 (2002); see also RESTATEMENT (THIRD) OF FOREIGN RELATIONS LAW $\S 206$ (1987) ("a state has sovereignty over its territory and general authority over its nationals.")

356 See supra Part II.

357 Commercial competitors, unlike other members of society, could understand litigation costs as a cost of doing business.

358 This is because the lawsuit is filed only after the saisie-gathered evidence becomes available to the potential plaintiff.

359 See supra Part IV.

360 TRIPS, supra note 341 at art. 39. 
pany patents, patent-directed evidence-gathering must extend special consideration to the protection of trade secrets. Discovery jurisprudence has established multi-factor analyses to evaluate whether certain trade secrets merit protection before Rule 34 production threatens their confidentiality. Such ex ante judicial interception better accommodates trade secrets from needless divulgation. The Saisie only provides for ex post inquiries into whether and to what extent harm was done. ${ }^{361}$ Rather than prevent the disclosure of trade secrets, it simply compensates for losses after such divulgation already occurred.

Lastly, discovery better accommodates confidential communications and information and, thereby, creates a better environment for prosecuting and defending valid patents. ${ }^{362}$ Frank exchanges between inventors and their legal representatives lead to better-drafted patent applications. ${ }^{363}$ Such communications also assist in defending against wrongful claims of invalidity or infringement and help identify and challenge invalid patents. The patent laws necessitate such lawsuits in order to maintain patent quality. Therefore, evidence gathering procedures should encourage open and frequent exchanges between inventors and their lawyers by shielding their contents from needless divulgation.

Discovery extends ex ante protection to privileged materials qualifying under the attorney-client privilege and the work product doctrine. ${ }^{364}$ United States courts enforce such privileges by way of protective orders if the parties cannot agree on an item's privileged nature. ${ }^{365}$ The Saisie does not exclude information on similar bases. Because privileges help foster frank communications and active cooperation between inventors and their legal advisors and representatives, discovery better promotes a procedural environment encouraging patent quality, validity and innovation in general. In that regard, Rule 34 discovery serves patent policy more proficiently than the Saisie does.

361 See supra Part III.

362 See supra Part II, B, 1.

363 See In re Spalding Sports Woldwide, 203 F.3d at $805-807$.

364 See supra Part II, B, 1.

365 See supra Part II, B, 2. 


\section{Conclusion}

In the wake of harmonization of procedural laws ${ }^{366}$ and increasing international pressure to enforce intellectual property rights, ${ }^{367}$ it is worth comparing, contrasting and evaluating the efficiencies of established pre-trial evidence-gathering procedures. ${ }^{368}$ Both the French Saisie-Contrefaçon and United States' Federal Rule of Civil Procedure 34 are extensively employed proof-procuring mechanisms in their respective home jurisdictions and in cross-border patent litigation. A closer look at the procedures themselves and the juridical concepts underlying their paternal legal systems shows that both mechanisms have responded, more or less effectively and efficiently, to particular needs of patent infringement cases. The Saisie, for example, is narrowly tailored to help seize proof of infringement. It yields limited, fast, directly relevant proof at a relatively low cost to both parties and does not unilaterally impose itself outside of France. Concurrently, it is extremely invasive; it offers little trade secret protection and fails to consider the need for openness between patentees or rightholders and their legal representatives. Rule 34, on the other hand, is broad, protracted, expensive, and extraterritorially applicable so as to make it internationally disfavored. As the same time, it properly puts the parties in charge of collecting evidence, and fosters open communication regarding rightholders' sensitive, patent-related information.

As countries pass procedural laws in order to meet their international obligations to enforce patents, ${ }^{369}$ they should beware of some key pre-trial features concerning patent litigation considered in this thesis. ${ }^{370}$ As the discussion above demonstrates, ex parte measures present an efficient way of extracting evidence that, otherwise, runs risk of destruction. Tailoring searchable and seizable evidence narrowly also reduces financial and timing burdens, which, otherwise could lead to abuses of pre-trial mechanisms. Further, protecting trade secrets and certain juridical information relating to patents on the litigation end, fosters experimentation and openness on the innovation and prosecution front. Lastly, because patents and the quarrels over them grow increasingly international, evidence-gathering procedures which respect both international norms and domestic procedures are apt to acquire cross-national acceptance.

366 See e.g. Baumgartner, supra note 323, at 1298 - 1307; Kevin M. Clermont, Integrating Transnational Perspectives into Civil Law Procedure: What Not to Teach, 56 J. LEGAL Educ. 524, 526 (2006) ("The subject of civil procedure is much bigger than its curricular pigeonhole."); Richard L. Marcus, Modes of Procedural Reform, 31 HASTINGS INT'L \& COMP. L. REV. 157 (2008).

367 See e.g. Enforcement Directive, supra note 308; TRIPS, supra note 341, at art. $41-43$.

368 See Richard L. Marcus, Putting American Procedural Exceptionalism into a Globalized Context, AM. J. CoMP. L. 709 (2005); Ronald J. Allen et al., The German Advantage in Civil Procedure: A Plea for More Details and Fewer generalities in Comparative Scholarship, 82 Nw. U. L. REV. 705, $706-736$ (1988).

369 See TRIPS, supra note 341 , at art. $41-43$.

370 For a similar endeavor outside of the patent context see Jan W. Bolt \& Joseph K. Wheatley, Private Rules for International Discovery in U.S. District Court: The U.S.-German Example, 11 UCLA J. INT'L L. AND FOREIGN AFF. 1 (2006). 
As business, trade, research and development as well as the provision of legal services and adjudication of patent disputes go international, it becomes increasingly important for countries to provide effective procedural laws for enforcing substantive patent rights. Guaranteeing adequate patent enforcement by way of effective pre-trial evidence gathering procedures presents a key way in which nations can attract honest businesses, thereby stimulating domestic trade, innovation, jobs-creation, and making use of of local tribunals and legal service providers. ${ }^{371}$ This allows a country to stay on the cutting edge of developing technologies and stimulate its economy. The employment of local courts, moreover, allows a country to help shape the development of international patent laws and cross-border patent enforcement. Thus, pre-trial measures providing well-defined, party-driven, ex parte searches while, concurrently, shielding trade secrets and sensitive patent-related information from disclosure and respecting extraterritorial limits best serve both international patent policy and domestic economics.

371 See David Perkins \& Gary Mills, Patent Infringement and Forum Shopping in the European Union, 20 FORDHAM INT'L L.J. 549 (1996). 


\section{List of Works Cited}

\section{Constitution and Legislations}

U.S. Const. art. I, $\S 8$, cl. 8 .

Code de la Propriété Intellectuelle (CPI).

Federal Rules of Civil Procedure (Fed. R. Civ. P.).

Nouveau Code de Procédure Civile (NCPC).

British Civil Procedure Rules (CPR).

\section{Cases}

Hickman v. Taylor, 329 U.S. 495 (1947).

Meese v. Eaton Mfg Co., 35 F.R.D. 162 (N.D. Ohio 1964).

V. D. Anderson Co. v. Helena Cotton Oil Co., 117 F.Supp. 932 (E.D. Ark. 1953).

Sibbach v. Wilson, 312 U.S. 1 (1941).

Miner v. Atlass, 363 U.S. 641,649 (1960).

Federal Deposit Ins. Corp. v. Cherry, Bekaert \& Holland, 131 F.R.D. 202 (M.D. Fla. 1990).

Japan Halon Co. v. Great Lakes Chem. Corp, 155 F.R.D. 626 (N.D. Ind. 1993).

Societe Internationale v. Rogers, 357 U.S. 197 (1958).

Nash v. City of Oakwood, 90 F.R.D. 633 (S.D. Ohio 1981).

Simon Prop. Group L.P., v. mySimon, Inc. 194 F.R.D. 639 (S.D. Ind. 2000).

Zalatuka v. Metropolitan Life Ins. Co., 108 F.2d 405 (C.A.7 1939).

Alford v. Northeast Ins. Co., 102 F.R.D. 99 (N.D. Fla. 1984).

Federal Sav. \& Loan Ins. Corp. v. Commonwealth Land Title Ins. Co., 130 F.R.D. 507 (D.D.C. 1990).

Daniels v. AMTRAK, 110 F.R.D. 160 (S.D.N.Y. 1986).

Financial Bldg. Consultants, Inc. v. American Druggists Ins. Co., 91 F.R.D. 59 (N.D. Ga. 1981).

Simon v. G.D. Searle \& Co., 119 F.R.D. 680 (D. Minn. 1987).

Fresenius Med. Care Holding Inc., v. Baxter Int'l, Inc., 224 F.R.D. 644 (2004).

E.I. Du Pont de Nemours v. Phillips Petroleum Co. 24 F.R.D. 416 (2006).

Alexander v. FBI, 194 F.R.D. 305 (D.D.C. 2000).

Harris v. Athol-Royalston Reg'l Sch. Dist. Comm., 200 F.R.D. 18 (D. Mass. 2001).

Micro Chem., Inc. v. Lextron, Inc., 193 F.R.D. 667 (D. Colo. 2000);

Eirhart v. Libbey-Owens-Ford Co., 93 F.R.D. 370 (N.D. Ill. 1981).

National Dairy Prods. Corp. v. L.D. Schreiber \& Co., 61 F.D.R. 581 (E.D. Wisc. 1973).

Harris v. Sunset Oil Co., 2 F.R.D. 93 (W.D. Wash. 1941).

Baine v. General Motors Corp., 141 F.R.D. 328 (M.D. Ala. 1991).

In re Air Crash Disaster at Detroit Metro. Airport, 130 F.R.D. 641 (E.D. Mich. 1989).

Scott v. Arex, Inc., 124 F.R.D. 39 (D. Conn. 1989)

Chaveriat v. Williams Pipe Line Co., 11 F.3d 1420 (7th Cir. 1993).

Riddell Sports Inc. v. Brooks, 158 F.R.D. 555 (S.D.N.Y. 1994).

American Soc'y for Prevention of Cruelty to Animals v. Ringling Bros. and Barnum \& Bailey

Circus, 233 F.R.D. 209 (D.D.C. 2006).

General Envtl. Sci. Corp. v. Horsfall, 136 F.R.D. 130 (N.D. Ohio 1991). 
Uniden America Corp. v. Ericsson, Inc., 181 F.R.D. 302 (M.D.N.C. 1998).

Hansen v. Dean Witter Reynolds Inc., 887 F. Supp. 669 (S.D.N.Y. 1995).

West v. Goodyear Tire \& Rubber Co., 167 F.3d 776 (2d. Cir. 1999).

Rush v. Artuz, 00 Civ. 3436, 2003 U.S. Dist. LEXIS 7158 (SD.N.Y. Apr. 3, 2003).

Financial Bldg. Consultants, Inc. v. American Druggists Ins. Co., 91 F.R.D. 59 (N.D. Ga 1981).

Digitraonics Corp. v. Jewel Cos., 57 F.R.D. 649 (N.D. Ill. 1972).

Nat'l Dairy Prod. Corp. v. L. D. Schreiber \& Co., 61 F.R.D. 581 (E.D. Wis. 1973).

V.D. Anderson Co. v. Helena Cotton Oil Co., 117 F.Supp. 932 (E.D. Ark. 1953).

Coca-Cola Bottling Co. of Shreveport, Inc. v. Coca-Cola Co., 110 F.R.D. 363 (D.Del. 1986).

U.S. v. Chen, 99 F.3d 1495 (9th Cir. 1996).

In re Spalding Sports Woldwide, 203 F.3d 800 (Fed. Cir. 2000).

Nestle Foods Corp. v. Aetna Casualty \& Surety Co., 129 F.R.D. 483 (D.N.J. 1990).

Alliance of End Repression v. Rochford, 75 F.R.D. 438 (N.D. Ill. 1976).

CA Aix-en-Provence, $1^{\text {er }}$ déc. 1976, PIBD 1977, $\mathrm{n}^{\circ}$ 186, III, 63, et Ann. propr. ind. 1978, 293.

TGI Paris, $3^{\mathrm{e}}$ ch., $2^{\mathrm{e}}$ sect., 12 oct. 2001, RD propr. int. 2002, $\mathrm{n}^{\mathrm{o}} 136$, p. 34 - TGI Paris, $3^{\mathrm{e}}$ ch.,

$2^{\mathrm{e}}$ sect., 23 déc. 2002, Propr. industr. 2003, comm. $\mathrm{n}^{\mathrm{o}} 58$.

TGI Paris, $3^{\mathrm{e}}$ ch., 29 mai 1987, RIPIA 1987, 180.

Cass. com., 26 avr. 2004, no 02-20.330, D. 2004, AJ, p. 1671.

CA Paris, $4^{\mathrm{e}}$ ch., 14 mars 1991, RD propr. ind. 1991, nº 34, 20, PIBD 1991, nº 506, III, 500.

TGI Paris, $3^{\mathrm{e}}$ ch., $3^{\mathrm{e}}$ sect., 15 oct. 2002, PIBD 2003, $\mathrm{n}^{\circ} 763$, III, 238.

CA Paris, $4^{\mathrm{e}}$ ch., 17 mai 1995, PIBD 1993, n592, III, 343.

Centurion Indus., Inc. v. Warren Steurer \& Assoc., 655 F.2d 288, 325 (10th Cir. 1981).

Petz v. Ethan Allen, Inc., 113 F.R.D. 494, 497 (D. Conn. 1985).

Zenith Radio Corp. v. Matsushita Elec. Indus. Co., 529 F. Supp. 866 (E.D. Pa. 1981).

Coca-Cola Bottling Co. v. Coca-Cola Co., 107 F.R.D. 288 (D. Del. 1985).

American Standard Inc. v. Pfizer, 828 F.2d 734 (Fed. Cir. 1987).

OpenTV v. Liberate Techs., 219 F.R.D. 474, (N.D. Cal. 2003).

Zubulake v. USB Warburg LLC, 216 F.R.D. 280 (S.D.N.Y. 2003).

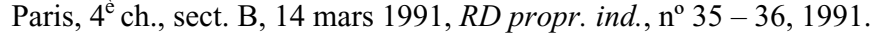

Anton Piller KG v. Manufacturing Processes [1976] Ch 55.

In re Pierre Bottled Water Litig., 138 F.R.D. 348, 354 (D.Conn. 1991).

Societe Nationale Industrielle Aerospatiale v. United States Dist. Ct., 482 U.S. 522 (1987).

R.M.S. Titanic, Inc. v. Haver, 171 F.3d 943 (4th Cir. 1999).

U.S. v. \$734,578.82 in U.S. Currency, 286 F.3d 641 (2002).

\section{Treaties and International Materials}

Council Directive 2004/48/EC, 2004 O.J. (L 157) 32 (EC).

World INTELlECTUAL PROPERTY ORGANIZATION, Advisory Committee on Enforcement, Second Session, Intellectual Property Litigation Under the Civil Law Legal System; Experience in Germany, WIPO/ACE/2/3 (June 4, 2004) (prepared by Joachim Bornkamm).

Hague Convention on the Taking of Evidence Abroad in Civil or Commercial Matters, opened for signature Mar. 18, 1970, 23 U.S.T. 2555.

Brief of the Government of the Federal Republic of Germany as Amicus Curiae in Support of Respondent, Societe Nationale Industrielle Aerospatiale v. United States Dist. Ct., 482 U.S. 522 (1986) (No. 85-1695).

Brief for the United States as Amicus Curiae, In re Anschuetz \& Co., GmbH, 754 F.2d 602 (5th Cir. 1985) (No. 85-98).

Agreement on Trade-Related Aspects of Intellectual Property Rights, Apr. 15, 1994, 33 I.L.M. 81 (1994). 
Stephen B. Burbank \& Linda J. Silberman, Civil Procedure Reform in Comparative Context: The United States of America, 45 AM. J. CoM. L. 675 (1997).

Note, Developments in the Law - Discovery, 74 HARV. L. REV. 940 (1961).

Edwin W. Green \& Douglas S. Brown, Back to the Future: Proposals for Restructuring Civil Discovery, 26 U.S.F. L. REV. 225 (1992).

Patrick E. Higginbotham, Foreword, 49 ALA. L. REV. 1 (1997).

Paul D. Carrington, Renovating Discovery, 49 ALA. L. REV. 51 (1997).

Thomas Y. Allman, The "Two-Tiered" Approach to E-Discovery: Has Rule 26(b)(2)(B) Fulfilled its Promise? 4 RICH J.L. \& TECH. 7 (2008).

Stephen C. Bruner, Discovery: An Ordered Approach, 30 FEDERATION Ins. Coun. Q. 205 (1980).

Christina M. Tchen et al., The Attorney-Client Privilege and Work-Product Doctrine in Internal Investigations: Protecting the Privilege: What Is It, Who Has It, and What Happens If You Waive It Good-Bye? 778 PLI/LIT 33 (2008).

Alvin K. Hellerstein, A Comparative Survey of the Attorney-Client Privilege and Work-Product Doctrine, 540 PLI/LIT 589 (1996).

Philippe Mueller, Ex Parte Search Orders for Securing Evidence of Infringement: Implementation Process of Directive 2004/48/EC of the European Parliament and of the Council of 29 April 204 on the Enforcement of Intellectual Property Rights, MAS-IP Diploma Papers \& Research Reports - Paper 26 (2005), available at

http://www.bepress.com/ndsip/papers/art26.

Boval, Sicherungs- und einstweilige Maßnahmen im Zusammenhang mit Patentverletzungsklagen in Frankreich, GRUR INT. 1993, 377.

Jochen Bühling, Obtaining Evidence When Preparing Patent Litigation, IP VALUE 2008, available at http://www.buildingipvalue.com/06EU/172_175.htm.

Pierre Véron, The "Saisie-Contrefacon": An Overview, in MIPLC Course Reader for "European Copyright Enforcement 2007/2008," on file with the author and the MIPLC administration.

Simon Cohen \& Martin Kohler, Disclosures in European Patent Litigation: Towards an Efficient Protection of Patent Owners, IP LITIGATOR (March 1, 2005), available at http:// www.accessmylibrary.com.

Paule Drouault-Gardrat, Enforcing Patent in France,, website, Bird \& Bird Articles Archive (Aug. 22, 2005), http://www.solutionslab.com/english/publications/books/index.cfm.

Bertoni et al., Forum Shopping Prospers Despite Enforcement Directive, MANAGING IP (July/ August 2008).

Daniel S. Drapeau, Anton Piller Orders: The Latest Word from the Supreme Court, the Federal Court of Appeal and the Federal Court, 20 InTELL. PROP. J. 39 (2006).

McKay, Compelling Discovery and Disclosure in Transnational Litigation: A Selected Bibliography, 16 N.Y.U. J. INT'L L. \& POL. 1217 (1984).

Kuo-Chang Huang, Mandatory Disclosure: A Controversial Device with No Effects, 21 PACE L. REV. 203 (2000).

Lee H. Rosenthal, A Few Thoughts on Electronic Discovery after December 1, 2006, 116 YALE L.J. POCKET PART 167 (2006).

Larry Coury, Note, C'est What? Saisie! A Comparison of Patent Infringement Remedies among G7 Economic Nations, 13 Fordham InTELl. Prop. Media \& ENT. L.J., 1101 (2003).

Jochen Bühling, Obtaining Evidence When Preparing Patent Litigation, IP VALUE 2008, available at http://www.buildingipvalue.com/06EU/172_175.htm.

Richard A. Egli, The Main Patent Litigation Countries in Europe, 366 PRAC. L. Inst./PAT. 35 (1993). 
Samuel Baumgartner, Is Transnational Litigation Different? 25 U. PA. J. INT'L ECON. L 1297 (2004).

Kevin M. Clermont, Integrating Transnational Perspectives into Civil Law Procedure: What Not to Teach, 56 J. LEGAL EDUC. 524 (2006).

Richard L. Marcus, Modes of Procedural Reform, 31 Hastings InT'L \& CoMP. L. REV. 157 (2008).

Ronald J. Allen et al., The German Advantage in Civil Procedure: A Plea for More Details and Fewer generalities in Comparative Scholarship, 82 Nw. U. L. REV. 705 (1988).

Richard L. Marcus, Putting American Procedural Exceptionalism into a Globalized Context, AM. J. COMP. L. 709 (2005).

Jan W. Bolt \& Joseph K. Wheatley, Private Rules for International Discovery in U.S. District Court: The U.S.-German Example, 11 UCLA J. INT'L L. AND FOREIGN AFF. 1 (2006).

David Perkins \& Gary Mills, Patent Infringement and Forum Shopping in the European Union, 20 FORDHAM INT'L L.J. 549 (1996).

\section{Books}

Kenneth R. Adamo et al., Document Discovery in Patent Litigation, in PATENT Litigation StRategies HandBooK 2004 Cumulative Supplement 79 (Barry L. Grossman \& Gary M. Hoffman eds., BNA Books 2004).

Oscar G. Chase et AL., Civil Litigation in Comparative ConteXt (2007).

ABBo JunKER, DisCOVERY IM DEUTSCH-AMERIKANISCHEN RECHTSVERKEHR (Otto Sandrock ed., Verlag Recht und Wirtschaft GmbH 1987).

Valerie Davies \& Thomas N. Pieper, English Disclosure and U.S. Discovery, in TransatLaNtic COMmercial Litigation And Arbitration, 233 (John Fellas ed., Oceana Publications 2004).

6 James WM. Moore et AL., Moore’s Federal Practice (Matthew Bender 3d ed. 2008).

7 James WM. MoOre et AL., MoOre's Federal Practice (Matthew Bender 3d ed. 2008).

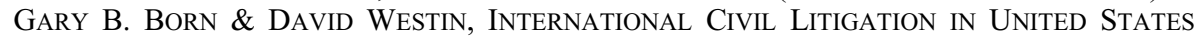
COURTS: COMMENTARY AND MATERIALS (Kluwer 1989).

Jack H. Frickenthal, Arthur R. Miller, John E. SeXton, And Helen Hershkoff, Civil Procedure: CASES AND MATERIALs (9th ed. 2005).

4 AM. JUR. Trials (2008).

23 AM. JUR. 2D Depositions and Discovery (2008).

JaCK B. Weinstein \& Margaret A. Berger, Weinstein's Federal EVidence $§ 900.01$ (Joseph M. McLaughlin ed., Matthew Bender 2d ed. 2005).

Black's Law Dictionary Pocket Edition (2d ed. 2004).

23 Charles Alan Wright et al., Federal Practice and Procedure (2d ed. 2008).

Kimberly A. Moore, Paul R. Michel \& Raphael V. Lupo, Patent Litigation and STRATEGY (2nd ed. 2003).

Raphael V. Lupo, Protective Orders, in PAtent Litigation Strategies Handbook 125

(Barry L. Grossman \& Gary M. Hoffman eds., BNA Books 2002).

Bizollon, Et AL., SAisie-Contrefacon (Véron ed., Dalloz 2d ed. 2005).

8 J. WigMORE, EVIDENCE (McNaughton rev. 1961).

Yves MARCELlin, LA SAisie-CONTREFACON (3d ed. Cedat 2001).

Rolf StÜrmer Et Al., Der JustizkonflikT Mit DEN VereinigTEN STAATEN VON AMERIKA (Walther J. Habscheid ed., Gieseking 1986).

RESTATEMENT (THIRD) OF FOREIGN RELATIONS LAW (1987).

Robert G. Bone, Civil Procedure: The Economics of Civil Procedure (Foundation Press 2003). 
Subcomm. on Patents, Trademarks, \& Copyrights of the S. Comm. on the Judiciary, 85th Cong., An Economic Review of the Patent System (Comm. Print 1958) (prepared by Fritz Machlup).

Convention for the Protection of Human Rights and Fundamental Freedoms, Nov. 4, 1950, 213 U.N.T.S. 222.

Pierre Véron, study, "Le contentiex des brevets d'invention, etude statistique 1990-1999," available at $\mathrm{http}: / / \mathrm{www} . v e r o n . c o m / i p l i b r a r y . p h p ? l a n g s=\mathrm{fr} \& S e s s i o n \_s i t e=\mathrm{f} 2 \mathrm{f5ffa} 20 \mathrm{~b} 8 \mathrm{e} 4$ cab0cb0ebac20b26add.

Interview with Judge Takami Shintaro, Associate Justice, Osaka District Court, Japan, in Munich, Germany (Aug. 26, 2008).

Allen \& Overy, website, available at http://www.allenovery.com/AOWEB/Knowledge/Editorial.aspx? contentTypeID=1\&contentSubTypeID=7945\&itemID=27083\&prefLangID=411. 